\section{OPEN ACCESS}

Edited by:

Anthony Grehan,

National University of Ireland Galway,

Ireland

Reviewed by:

Michail M. Yakimov,

Italian National Research Council, Italy

Daniela Zeppilli,

Institut Français de Recherche pour

l'Exploitation de la Mer (IFREMER),

France

${ }^{*}$ Correspondence:

Nadine Le Bris

lebris@obs-banyuls.fr

Specialty section:

This article was submitted to

Deep-Sea Environments and Ecology,

a section of the journal

Frontiers in Marine Science

Received: 18 July 2018

Accepted: 31 December 2018

Published: 18 January 2019

Citation:

Le Bris N, Yücel M, Das A,

Sievert SM, LokaBharathi $P$ and

Girguis PR (2019) Hydrothermal

Energy Transfer and Organic Carbon

Production at the Deep Seafloor.

Front. Mar. Sci. 5:531.

doi: 10.3389/fmars.2018.00531

\title{
Hydrothermal Energy Transfer and Organic Carbon Production at the Deep Seafloor
}

\section{Nadine Le Bris ${ }^{1 *}$, Mustafa Yücel ${ }^{2}$, Anindita Das ${ }^{3,4}$, Stefan M. Sievert ${ }^{5}$, PonnaPakkam LokaBharathi ${ }^{4}$ and Peter R. Girguis ${ }^{6}$}

\begin{abstract}
'Laboratoire d'Ecogéochimie des Environnements Benthiques, Observatoire Océanologique de Banyuls, CNRS, Sorbonne Université, Banyuls-sur-Mer, France, ${ }^{2}$ Institute of Marine Sciences, METU-IMS, Middle East Technical University, Mersin, Turkey, ${ }^{3}$ Agharkar Research Institute, Maharashtra Association for the Cultivation of Sciences (ARI-MACS), Pune, India, ${ }^{4}$ Academy of Scientific and Innovative Research (AcSIR), CSIR - National Institute of Oceanography, Goa, India, ${ }^{5}$ Biology Department, Woods Hole Oceanographic Institution, Woods Hole, MA, United States, ${ }^{6}$ Department of Organismic and Evolutionary Biology, Harvard University, Cambridge, MA, United States
\end{abstract}

In just four decades, hundreds of hydrothermal vent fields have been discovered, widely distributed along tectonic plate boundaries on the ocean floor. Vent invertebrate biomass reaching up to tens of kilograms per square meter has attracted attention as a potential contributor to the organic carbon pool available in the resource-limited deep sea. But the rate of chemosynthetic production of organic carbon at deep-sea hydrothermal vents is highly variable and still poorly constrained. Despite the advent of molecular techniques and in situ sensing technologies, the factors that control the capacity of vent communities to exploit the available chemical energy resources remain largely unknown. Here, we review key drivers of hydrothermal ecosystem productivity, including (a) the diverse mechanisms governing energy transfer among biotic and abiotic processes; (b) the tight linkages among these processes; and (c) the nature and extent of spatial and temporal diversity within a variety of geological settings; and (d) the influence of these and other factors on the turnover of microbial primary producers, including those associated with megafauna. This review proposes a revised consideration of the pathways leading to the biological conversion of inorganic energy sources into biomass in different hydrothermal habitats on the seafloor. We propose a conceptual model that departs from the canonical conservative mixing-continuum paradigm by distinguishing low-temperature diffuse flows (LT-diffuse flows) derived from seawater and high-temperature fluids (HT-diffuse flow) derived from end-member fluids. We further discuss the potential for sustained organic matter production at vent-field scale, accounting for the natural instability of hydrothermal ecosystems, from the climax vent communities of exceptional productivity to the long-term lower-activity assemblages. The parameterization of such a model crucially needs assessment of in situ rates and of the largely unrecognized natural variability on relevant temporal scales. Beyond the diversity of hydrothermal settings, the depth range and water mass distribution over 
oceanic ridge crests, volcanic arcs and back-arc systems are expected to significantly influence biomass production rates. A particular challenge is to develop observing strategies that will account for the full range of environmental variables while attempting to derive global or regional estimates.

Keywords: chemosynthetic biological communities, hydrothermal ecosystem, diffuse flow fluids, habitat diversity, redox gradients, carbon-fixation, productivity, deep-sea organic carbon

\section{INTRODUCTION}

Deep-sea hydrothermal vent exploration has progressively intensified over the last 40 years, since the discovery of lowtemperature diffuse flows in 1977 and of high-temperature black smokers in 1979 on the Galapagos Ridge and East Pacific Rise, respectively (Corliss et al., 1979; Spiess et al., 1980). By 2009, more than 250 vents were visually confirmed (Beaulieu et al., 2013), and about the same number have been inferred from chemical and physical tracers of hydrothermal plumes in the water column. Hydrothermal vents encompass various types of fluid flows observed at the seafloor, whose temperatures range from a few tens of degrees above background seawater up to $410^{\circ} \mathrm{C}$ at black smoker orifices (Beaulieu et al., 2013). The number of known "vent fields," i.e., areas hosting a vent network typically distributed over a few square kilometers, is rapidly growing and includes a variety of geophysical settings along mid-ocean ridges (MOR), as well as volcanic arcs and backarc spreading systems (ABA) (German et al., 2011; Beaulieu et al., 2013, 2015; Baker et al., 2016). Broadly speaking, the abundance of chemolithoautotrophic microorganisms, which are capable of fixing inorganic carbon to organic carbon by using energy from oxidation-reduction chemical reactions (McCollom and Shock, 1997; Takai and Nakamura, 2011; Nakamura and Takai, 2014) provides a local source of primary production, and thus sustains much higher invertebrate biomasses than in the surrounding deep-sea (Tunnicliffe et al., 2003). Recent attempts to assess the contribution of vent ecosystems to the global ocean organic carbon budget have shown that the energy flux available for $\mathrm{CO}_{2}$ fixation is orders of magnitude lower than that for photosynthesis (Olins et al., 2013; Nakamura and Takai, 2014; McNichol et al., 2018). Nevertheless, these chemosynthetic productivity hotspots interact with the surrounding deep-sea environments, providing labile organic resources to benthic and pelagic ecosystems that receive limited input from photosynthetic production (Levin et al., 2016). Indeed, vent-derived organic carbon flux supplements the metazoan food web much beyond the areas where hydrothermal venting occurs (Bell et al., 2017). Furthermore, chemosynthetic carbon exerts an influence at larger ocean scale, through the formation of complexes of metals like iron or copper issued from vents with organic ligands (Bennett et al., 2008; Sander and Koschinsky, 2011; Sands et al., 2012; Hoffman et al., 2018), hence contributing to the global ocean micronutrient budgets (Tagliabue et al., 2010; Wu et al., 2011; Hawkes et al., 2013; Fitzsimmons et al., 2014; Resing et al., 2015). As anthropogenic pressures intensify on these environments with the prospects of industrial mineral mining (Halfar and
Fujita, 2007; Van Dover, 2011; Collins et al., 2013; Mengerink et al., 2014) and the exploitation of other deep-sea resources (Ramirez-Llodra et al., 2010; Santos et al., 2012), assessing ecological functions and the services they support warrants greater attention (Boschen et al., 2013). We posit that a more critical examination of the functional role of hydrothermal ecosystems is needed, not only in target areas of anthropogenic disturbance (Gollner et al., 2017), but also on a more conceptual basis in order to consider their significance in a broader deepocean context.

With the growing knowledge of the geochemical, biogeochemical and ecological diversity of deep-sea vents, the possibility of a more comprehensive understanding of these drivers has recently emerged. In particular, a diversity of microbial carbon fixation pathways has now been elucidated in habitats as diverse as hydrothermal edifices, diffuse flow zones on sulfide precipitates or seafloor basalts and sediments hosting hydrothermal seepage. Yet the factors constraining organic matter production by these microbial primary producers remain largely unknown. Whereas recent review papers have examined this question in the sub-seafloor (Orcutt et al., 2011) or along hydrothermal plumes (Dick et al., 2013), a fully integrated synthesis bridging the knowledge of different disciplinary fields, encompassing the wide diversity of vent systems, is still lacking for seafloor hydrothermal vent habitats that are associated with the largest biomasses. A comprehensive understanding of the mechanisms driving the efficiency of energy transfer and $\mathrm{CO}_{2}$-fixation pathways across diverse hydrothermal habitats additionally requires accounting for the ephemeral nature of vent systems. For example, the rise and decline of populations monitored over years on recent massive lava flows on fast-spreading ridges have been attributed to the interplay of changes in end-member fluid composition (Fustec et al., 1987; Shank et al., 1998; Tsurumi and Tunnicliffe, 2001) and species dispersal capacities (Mullineaux et al., 2000, 2003, 2010, 2018; Adams et al., 2011). Such pulses of organic carbon may have a profound influence on the oligotrophic deep-sea biota, which often thrive on an intermittent resource supply on decadal or longer timescales (Glover et al., 2010). Conversely, relatively stable, fluid composition and invertebrate populations were described on slow-spreading ridges over decades (Cuvelier et al., 2011; Du Preez and Fisher, 2018), suggesting a more continuous supply of organic production to peripheral areas in these contexts. There is, however, a critical lack of information on the temporal dynamics for most of the known vent fields, and especially on the volcanic arcs and back-arc systems, which have been rarely revisited (Du Preez and Fisher, 2018). 


\section{FROM GEOFUELS TO CHEMOLITHOAUTOTROPHS}

\section{The Mosaics of Hydrothermal Energy Hotspots}

Vent fluids transport a variety of chemically reduced compounds, primarily sulfide, methane, hydrogen, iron and manganese, in variable proportions from the deep crust to the seafloor (German and Von Damm, 2004). The supply of these so-called "geofuels" (Bach et al., 2006), along with the abundance of chemicallyoxidized species (e.g., oxygen, nitrate and sulfate) in deep seawater, provides a geochemical haven for chemolithotrophic microbes, especially at the interface where vent and seawater mixes. Chemolithotrophic microbes harness energy from these reduction-oxidation reactions, and use that energy to support carbon fixation. Along MOR and ABA, distinct properties of basement rocks such as basalts, peridotites and felsic rocks are believed to govern the concentration of reduced chemicals in hydrothermal fluids formed at high temperature and pressure (Von Damm, 1995; Ishibashi et al., 2014; German and Seyfried, 2014) (Figure 1). Back-arc $\mathrm{SO}_{2}$-rich fluids are particularly influenced by subducted material and magma degasing, and transport intermediate redox states of sulfur $\left(\mathrm{S}^{\circ}, \mathrm{S}_{2} \mathrm{O}_{3}{ }^{2-}\right)$ and nitrogen $\left(\mathrm{NH}_{4}{ }^{++}\right)$that can contribute to the flux of geofuels (Resing et al., 2007; Butterfield et al., 2011; German and Seyfried, 2014). More generally, the heterogeneous structure and topography of the seafloor with variable depth, spreading rate, magmatic and tectonic activity, further creates tremendous differences in geofuel concentrations among high-temperature end-member fluids, even among proximal vent fields along MOR and ABA.

The concentrations of sulfide $\left(\mathrm{S}^{-\mathrm{II}}\right)$ and ferrous iron $\left(\mathrm{Fe}^{\mathrm{II}}\right)$, two key players in geochemical and biogeochemical hydrothermal processes, are particularly variable. Sulfide in end-member fluids ranges from 0 to $19.5 \mathrm{mmol} \mathrm{kg} \mathrm{m}^{-1}$ and 1 to $13.1 \mathrm{mmol} \mathrm{kg}^{-1}$, respectively on MOR and ABA, with outliers reported for ultrafast spreading ridges following volcanic eruptions (e.g., $110 \mathrm{mmol} \mathrm{kg}^{-1}$, German and Von Damm, 2004; Tivey, 2007; Gartman et al., 2014). Iron concentrations in end-member fluids are slightly higher on MOR (0.007$24 \mathrm{mmol} \mathrm{kg}-1)$ than on ABA (0.01-13.0 mmol kg$\left.{ }^{-1}\right)$, though the ABA systems are undersampled so this generalization is not robustly supported (Gartman et al., 2014; Nakamura and Takai, 2014). Additionally, the ridge spreading-rate is thought to be a determining factor of the ranges of sulfide and iron in endmember fluids, with a decrease in sulfide and an increase in iron with decreasing spreading rate (Gartman et al., 2014). On back-arcs, the proximity to the associated volcanic arc within tens of kilometers further adds to this variability. The Eastern Lau Spreading Center (ELSC) where the Mariner vent field hosts substantially metal-enriched end member fluids provides striking examples of such geochemical contrasts within short geographical distances, with sulfide and iron concentrations ranging from 1.2 to $9.3 \mathrm{mmol} \mathrm{kg}{ }^{-1}$ and 0.14 to $13 \mathrm{mmol} \mathrm{kg}^{-1}$, respectively (Mottl et al., 2011; Reeves et al., 2011; Yücel et al., 2011).
On slow-spreading ridges, tectonics shape the structure of the ridge axis and further creates differences in geofuel contents in fluids (Allen and Seyfried, 2004; Cannat et al., 2010). Exposure of mantle rocks to the hydrothermal circulation induces serpentinization and generates serpentine-hosted end-member fluids that are distinguishable from basalt-hosted ones by their high concentrations of $\mathrm{H}_{2}$ and methane (Charlou et al., 2002, 2010; Proskurowski et al., 2008). Described from the late 1990s' on the Mid-Atlantic Ridge (Charlou et al., 2002; Schmidt et al., 2007) and Central Indian Ridge (Gamo et al., 2001; Gallant and Von Damm, 2006; Kumagai et al., 2008), end-member fluids display hydrogen concentrations up to $26 \mathrm{mmol} \mathrm{kg}^{-1}$ at Rainbow (Charlou et al., 2010). In comparison, hydrogen remains low in ABA fluids (0.035-0.5 mmol kg-1 (German and Von Damm, 2004). $\mathrm{CH}_{4}$, a by-product of the abiotic reaction of $\mathrm{H}_{2}$ with $\mathrm{CO}_{2}$ at high temperature and pressure, also reaches unusually high values in serpentine-hosted endmember fluids [e.g., up to $3.5 \mathrm{mmol} \mathrm{kg}{ }^{-1}$ at Logatchev (Schmidt

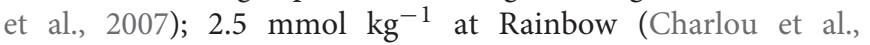
2002)]. Methane usually does not exceed $0.15 \mathrm{mmol} \mathrm{kg}^{-1}$ in end-member fluids of basalt-hosted vent fields (German and Von Damm, 2004), except for the two shallower vent fields of the Mid-Atlantic Ridge. Menez Gwen and Lucky Strike endmember fluids reach up to 2.6 and $1.0 \mathrm{mmol} \mathrm{kg}-1$, respectively (Charlou et al., 2002). The discovery of the Lost City vent field expanded the geographical distribution of hydrogen and methane-rich hydrothermal systems further from spreading axes, by revealing the occurrence of hydrothermal circulation on a 1.5Myr-old crust in the absence of recent magmatic influence at the intersection of the Mid-Atlantic Ridge and the Atlantis fracture zone (Kelley et al., 2001, 2005). Departing from other known hydrothermal end-member fluids, Lost City alkaline fluids (up to $\mathrm{pH}$ 10) are rich in hydrogen (up to $14 \mathrm{mmol} \mathrm{kg}^{-1}$ ) and methane (up to $2 \mathrm{mmol} \mathrm{kg}^{-1}$ ) with moderately warm temperatures (up to $90^{\circ} \mathrm{C}$ ), while comparatively low in sulfide (up to $0.5 \mathrm{mmol} \mathrm{kg}{ }^{-1}$ ) and depleted in iron and other metals (Kelley and Shank, 2010). Though the heat source driving the hydrothermal circulation at Lost City is still debated, the relatively low temperature and unique composition of end-member fluids point to the dominant role of serpentinization (Allen and Seyfried, 2004). Additional examples of this novel class of hydrothermal systems were discovered at 5550-5900 m-deep site on a steep scarp of the Mariana trench (Ohara et al., 2012) as well as on the western flanks of the ultraslow spreading Mid-Cayman Spreading Centre (Connelly et al., 2012; Hodgkinson et al., 2015).

Owing to the tectonic and volcanic processes driving hydrothermal circulation, each end-member fluid issuing from a black smoker edifice is truly unique in both space and time. That said, some vent fields display remarkable homogeneity, reflecting a single subsurface source as, for example, the Rainbow vent field on the MAR (Charlou et al., 2002). However, differences in end-member fluids compositions among high-temperature vents within a vent field can result from discontinuous axial magma chamber fuelling different sub-seafloor plumbing systems (e.g., at $9^{\circ} 50^{\prime} \mathrm{N}$ on the East Pacific Rise, Main Endeavor on the Juan de Fuca Ridge or Lucky Strike on the Mid-Atlantic Ridge) (Von Damm, 1995; Wankel et al., 2011; Barreyre et al., 2014). 


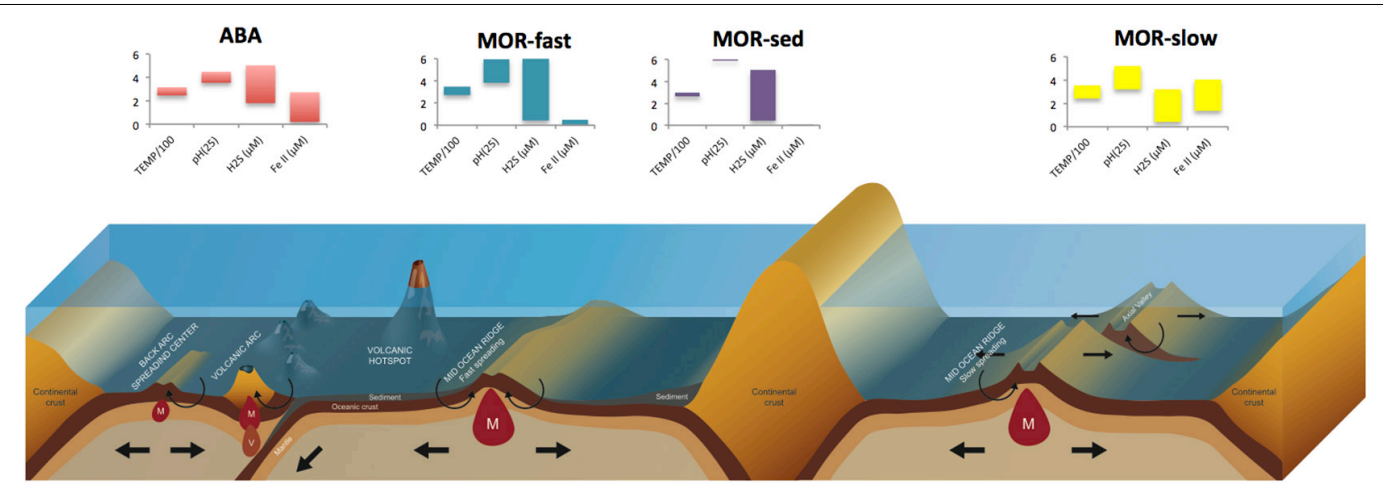

FIGURE 1 | Different types of vent fields on Arc and Back-arc systems (ABA), Mid-Ocean Ridges (MOR) of fast-spreading (fast), slow-spreading (slow) and sedimented accretion centers. Histograms illustrate the variability of dominant electron-donors in end-member fluids and their temperature range (TEMP/100 in ${ }^{\circ} \mathrm{C}$ ).

Locally, sub-seafloor phase separation, generating two types of fluids derived from a metal-rich brine phase and a vapor phase enriched in volatiles, can be a main factor of intra-field variability (Von Damm, 1995; German and Von Damm, 2004; German and Seyfried, 2014). Phase-separation can even generate differences between black smokers at the scale of a single large edifice, as shown on the $21^{\circ} \mathrm{S}$ EPR Napa Nui vent field (Von Damm et al., 2003).

\section{Thermodynamic Estimates of Chemical Energy Availability}

Linking the energy available for chemolithoautotrophs to the fluxes of electron donors and acceptors in diverse hydrothermal contexts remains in its infancy. To this end, geochemical constraints on the most energy-yielding reactions have been explored using thermodynamic models. The first model developed by McCollom and Shock (1997) used a fluid composition similar to the composition of the first high temperature fluids found at $21^{\circ} \mathrm{N}$ along the East Pacific Rise, as well as east-Pacific abyssal waters, to calculate the Gibbs free energy available per $1 \mathrm{~kg}$ of end-member vent fluid along a dilution gradient (and assuming no consumption of electron donor or acceptor during mixing with seawater). Later, Amend et al. (2011) applied this model to hydrothermal systems hosted in different basement rocks and estimated a much higher energetic potential for aerobes that oxidize hydrogen, methane, sulfide and iron with oxygen than anaerobes that use hydrogen oxidation coupled to sulfate reduction and methanogenesis. For example, at the Rainbow vent field, the energy available from $1 \mathrm{~kg}$ of end-member fluid is estimated to range from 1 to $7 \mathrm{~kJ}$. For the same amount of fluid, the oxidation of hydrogen with oxygen at high dilution rates (e.g., where the ratio of seawater to pure vent fluid is $>50$ ) would be 4 times more energetic than with sulfate at a lower dilution ratio (where the ratio of seawater to pure vent fluid is $<10$ ). The oxidation of hydrogen with oxygen also yields twice the energy available from methane, and almost four times the energy available from sulfide at Rainbow (McCollom, 2007). This author estimated that, even assuming a $10 \%$ efficiency, up to $70 \mathrm{t} \mathrm{y}^{-1}\left(8 \mathrm{~kg} \mathrm{~h}^{-1}\right)$ of biomass could be produced at the vent field scale for a discharge flux of $450 \mathrm{~L} \mathrm{~h}^{-1}$. Similar thermodynamic estimates suggested that iron oxidation at Loihi seamount in the Hawaiian archipelago could still support approximately $7.3 \mathrm{t} \mathrm{y}^{-1}\left(20 \mathrm{~kg} \mathrm{~d}^{-1}\right)$ of biomass of carbon at vent field scale, despite the low thermodynamic energy yield of the aerobic oxidation of $\mathrm{Fe}^{\mathrm{II}}$ (Edwards et al., 2005).

Nakamura and Takai (2014) used a similar approach to compare potentially predominant energy sources for a series of 89 vent fields. Their assessment encompasses $\mathrm{H}_{2}$ and $\mathrm{CH}_{4}{ }^{-}$ rich fluids from ultramafic settings, such as Rainbow (MidAtlantic Ridge) and Kairei (Central Indian Ridge), hydrothermal fluids enriched with reduced sulfur compounds from mafic to felsic rocks such as Mariner, Brothers Caldera NW and Toto Caldera and typical fluids of sediment-associated systems with unusual enrichment in $\mathrm{CH}_{4}$ and $\mathrm{NH}_{4}{ }^{+}$from the Guaymas basin, Iheya North and Yonaguni Knoll IV. Their model identifies $\mathrm{H}_{2} \mathrm{~S}$ as a predominant energy source for all vent systems, except at a very low end-member fluid/seawater dilution ratio, but also showed that variations in $\mathrm{H}_{2} \mathrm{~S}$ concentrations in endmember fluids had little effect on the energy available for thiotrophs. Furthermore, they suggested that the available energy is poorly dependent on the mixing rate, suggesting that $\mathrm{H}_{2} \mathrm{~S}$ may not be limiting for primary production. The limiting factor for the calculated energy, instead, is the availability of oxygen (the only electron acceptor considered in the model for sulfide oxidation). This study did not consider the variable oxygen content of bottom seawater and, for this reason, may not have fully captured the full range of energetic constraints exerted on microbes. In $\mathrm{H}_{2}$-rich ultramafic rockhosted hydrothermal systems, however, anaerobic and aerobic hydrogenotrophy appears energetically favored compared to thiotrophy (Nakamura and Takai, 2014). In contrast to sulfide, variations in $\mathrm{H}_{2}$ concentrations in hydrothermal fluids do significantly affect the energy available for aerobic and anaerobic hydrogenotrophs. Similarly, the concentration of methane in fluids is suggested to have a considerable impact on microbes with aerobic and anaerobic methanotrophic metabolisms, in both ultramafic-hosted and sediment-associated hydrothermal systems. 
The comparison of thermodynamic estimates with the production of biomass remains critical, as ground-truthing of these models is particularly difficult. If archaeal cell counts were shown to correlate positively with the available energy estimate at one vent (per kilogram of mixed fluids; Takai and Nakamura, 2011), what is observed for anaerobic hyperthermophilic archea in chimney walls might not hold true for aerobes exposed to variable flows of electron donors and acceptors that are expected to dominate the chemosynthetic primary production. Furthermore, observations of biomass-dominant fauna can contrast with model estimates. The biomass of invertebrate assemblages at Rainbow, for instance, is relatively low compared to basalt-hosted vent fields of this region of the Mid-Atlantic Ridge (Gebruk et al., 2000; Desbruyères et al., 2001), suggesting additional constraints on the microbial use of available energy provided by hydrogen and methane-rich fluids.

Carbon-fixation rate values as high as 80.2 and $3.510^{4} \mathrm{gC} \mathrm{m}^{-3} \mathrm{y}^{-1}$ have been reported from incubated fluids and microbial mats from hydrothermal systems, respectively (Das et al., 2011; Thomas et al., 2018). A critical need, however, is to better constrain the energy yields for vent chemolithoautotrophs in conditions truly representative of vent habitats. Recently, first empirical estimates for primary production, standing stock, and turnover of the sub-seafloor biosphere at deep-sea vents were obtained using incubations conducted at in situ pressure and temperature, yielding rates as high as $117 \mathrm{gC} \mathrm{m}^{-3} \mathrm{y}^{-1}$ (McNichol et al., 2018). First quantitative estimates of in situ carbon fixation rates in different microhabitats of black smoker chimneys confirmed higher rates of $\mathrm{CO}_{2}$-fixation at low temperature corresponding to aerobic conditions but did not reveal obvious correlations with local geochemical conditions (Olins et al., 2013). Beyond the inventory of geofuels and thermodynamic estimates, assessments of the chemoautotrophic production potential still require an in-depth analysis of factors limiting energy acquisition in vent microhabitats.

\section{The Metabolic and Functional Diversity of Vent Chemolithoautotrophs}

Linking chemoautolithotrophic production rates with biotic and abiotic factors is particularly challenging, owing to the diversity of metabolic pathways among vent microbial communities. A large number of cultivation-dependent and -independent studies have shed light on the range of metabolic pathways used by chemoautotrophic bacteria and archaea to fix $\mathrm{CO}_{2}$ (Campbell et al., 2006; Takai et al., 2006; Nakagawa and Takai, 2008; Huber and Holden, 2008; Böhnke and Perner, 2017). These include: (1) the Calvin-Benson (CBB) cycle, (2) the reductive or reverse TCA cycle (rTCA), (3) the acetyl CoApathway, (4) the 3-hydroxypropionate bicycle, -chloroflexaceae, (5) the dicarboxylate/4-hydroxybutyrate cycle and (6) 3-the hydroxypropionate/4-hydroxybutyrate cycle (Berg, 2011; Hügler and Sievert, 2011). The higher energy demand and higher productivity of aerobic metabolisms (CBB cycle, 3-HP bicycle, 3-HP/4-HB cycle) suggest that these pathways would dominate primary production in well-oxygenated conditions (Hügler and Sievert, 2011). Conversely microbes using the oxygen-sensitive enzymes of reductive acetyl-CoA, rTCA, DC/4-HB pathways will dominate anoxic or microaerophilic conditions. Both enzymatic and genomic evidence indeed supports the widely distributed use of rTCA in Aquificales and Epsilonproteobacteria (now classified as Campylobacteria) (Waite et al., 2017) that are frequently abundant members of vent microbial communities (Shiba et al., 1985; Deckert et al., 1998; Hügler et al., 2005, 2007; Takai et al., 2006; Huber et al., 2007; Nakagawa et al., 2007; Sievert et al., 2008; Reysenbach et al., 2009; McNichol et al., 2016, 2018). Due to the vast phylogenetic diversity and as-yet uncultivated status of most vent microbes, their quantification and the quantification of their activity in natural settings are still very challenging, although progress has been made more recently (McNichol et al., 2016).

It is generally considered that the dominant primary producers in vent habitats harness energy from the oxidation of major electron donors transported in vent fluids: sulfide, hydrogen, methane and iron. Sulfide-oxidizing aerobes are considered key primary producers at vents (Sievert et al., 2008). Thiosulfate, a product of incomplete abiotic sulfide oxidation that can reach substantial concentrations in some ABA hydrothermal habitats (Gartman et al., 2011), is also utilized by metabolically diverse Campylobacteria and Gammaproteobacteria (Campbell et al., 2006; Nakagawa and Takai, 2008). Campylobacteria are dominant microbial community members of the sub-seafloor biosphere as well as early colonizers in low-temperature hydrothermal environments and as such play a primary role in carbon fixation at vents (Alain et al., 2004; Huber et al., 2007; Gulmann et al., 2015; McNichol et al., 2016; Meier et al., 2017). Recent studies also point to the capacity of vent chemolithoautotrophs to derive energy from hydrogen oxidation (Takai et al., 2004; Petersen et al., 2011; Sanders et al., 2013; McNichol et al., 2016, 2018). Hydrogen-oxidizers have been isolated from various deep-sea hydrothermal vent fields, in association with epibiont-bearing invertebrates or from biofilms formed in chimney wall, including Aquificales, Campylobacteria (Epsilonproteobacteria), Desulfurococcales, Methanococcales, Thermodesulfobacteriales and Deferribacterales (Nakagawa and Takai, 2008).

Sulfur-cycling microbes at vents are also able to use reduced sulfur compounds autotrophically with oxygen or nitrate as electron acceptors (Amend et al., 2004; Takai et al., 2006; Nakagawa and Takai, 2008; Hügler et al., 2010; Yamamoto and Takai, 2011; Sievert and Vetriani, 2012; McNichol et al., 2016, 2018). There are basically two sulfide-oxidation pathways: the socalled SOX pathway, and the reverse-sulfate reduction pathway, the latter of which involves APS reductase and dissimilatory sulfide reductase (DSR) (Sievert et al., 2008; Nakagawa and Takai, 2008; Yamamoto and Takai, 2011). In sulfur-oxidizing Gammaproteobacteria, the latter may also be combined with an incomplete SOX system (missing soxCD) to oxidize thiosulfate, in which case thiosulfate is oxidized to elemental sulfur, followed by its oxidation to sulfate via the reverse DSR pathway. Campylobacteria and some gammaproteobacteria like Thiomicrospira have the complete SOX pathway, which they use to oxidize reduced sulfur compounds such as elemental sufur, polysulfide, and thiosulfate and possibly sulfide to sulfate, while using the sulfide-quinone reductase to oxidize sulfide to 
elemental sulfur (Nakagawa and Takai, 2008; Sievert et al., 2008). The combination of sulfur oxidation via the SOX pathway and carbon fixation via the rTCA pathway has been shown to be ubiquitous in Campylobacteria (Nakagawa and Takai, 2008).

Less is known about the potential importance of organic carbon production pathways associated with other chemosynthetic processes, such as methanogenesis, methane oxidation and iron oxidation in deep-sea vent habitats. The majority of methanogenic microorganisms that thrive in hydrothermal vents, like Methanococcales (e.g., Methanocaldococcus and Methanothermococcus) and Methanopyrales (i.e., Methanopyrus) use the reductive acetylCoA pathway for carbon fixation (Ragsdale and Pierce, 2008; Weiss et al., 2016). Methanotrophs are not "autotrophs" in the strictest sense, but they are primary producers in vent fields where methane is produced abiotically, e.g., serpentine-hosted vents, and play a significant role in primary production in symbiosis with invertebrates forming dense fauna aggregations. While aerobic methanotrophs are abundantly represented in bivalve symbionts, the anaerobic free-living methanotrophs, the so-called ANME I group, have also been described from the Lost City chimneys in association with sulfate reducing bacteria (Brazelton et al., 2006), as well as for some vent sites of the Von Damm complex on the Cayman Rise (Reveillaud et al., 2016). In iron-rich environments, iron oxidizers like Zetaproteobacteria, known to use the Calvin-Benson-Bassham cycle, can sustain significant biomass production. Mariprofundus ferrooxydans dominates thick iron oxide mats formed around vents on the flanks of the Loihi Seamount submarine volcano (Emerson and Moyer, 2002) and flourishes on iron-rich talus and other rubble at TAG and other hydrothermal vent mounds (Mori et al., 2017). Nevertheless, next generation sequencing techniques (e.g., pyrosequencing and DNA-microarrays) have started to shed light on the complexity and functional diversity of vent microbes (He et al., 2007). As an example, the sequences obtained from a black smoker chimney in the Mothra vent field at the Juan de Fuca Ridge revealed that sulfur oxidation, putatively coupled to nitrate reduction, was mainly used to perform inorganic carbon fixation through the Calvin-Benson-Bassham cycle (Xie et al., 2011). The high-throughput metagenomics study conducted by Wang et al. (2009) further revealed differences in microbial metabolic functions in the inner and outer section of a newly grown chimney at the Juan de Fuca Ridge. With only around 1\% common microbial functional genes, the microbial communities are not only metabolically and physiologically highly diverse, but also appear to undergo dynamic succession and adaptation in response to the steep temperature and chemical gradients across the rapidly growing chimney.

More complex interactions than inferred from available energy budgets and metabolic capabilities are yet suggested between the activity of microbial communities and the geochemical conditions of their habitats (Campbell et al., 2013; Reveillaud et al., 2016; Meier et al., 2017). Metagenomic studies are just starting to shed light on this aspect, e.g., revealing niche partitioning between different sulfur-oxidizing Campylobacteria with distinct patterns of genes involved in reducing oxidative stress in response to the increased oxygen concentrations in their microhabitat (Meier et al., 2017). These studies point to the need for an improved characterization of microscale environmental gradients and the processes underlying them to assess the $\mathrm{CO}_{2}$-fixing capacity of free-living microbes developing at the surface and within porous substrates in vent ecosystems. The extent of this sub-seafloor biosphere itself remains a major unknown, despite efforts to sample it by deep-drilling or by collecting diffuse fluids (Takai et al., 2004; Huber et al., 2007) and recent work that tried putting constraints on its standing stock and turnover (Robidart et al., 2013; McNichol et al., 2018).

\section{Versatile and Flexible Symbiotic Associations}

One of the most striking features conserved across vent ecosystems from MOR and ABA is their epibenthic biomass dominated by symbiont-containing invertebrates. In contrast to the vast diversity of free-living chemolithoautotrophs, there are relatively few chemolithoautotrophic symbionts that form obligate associations with vent invertebrates (Fisher et al., 2007; Dubilier et al., 2008). "Holobionts" (i.e., the intact assemblage of symbionts and their host invertebrates) can be considered major primary producers of the hydrothermal ecosystem, similar to corals in tropical reef ecosystems. However, biomass estimates are still relatively rare for vent populations, owing to the difficulties to quantitatively collect biological assemblages for a precisely defined given seafloor area (Govenar et al., 2005). Improvement of image resolution now offers alternative methods to estimate minimal biomasses from the visible individuals forming 3Dassemblages (Juniper et al., 1998; Gebruk et al., 2000; Cuvelier et al., 2012). Biomass estimates as high as $70 \mathrm{~kg} \mathrm{~m}^{-2}$ (wet weight with shells) were reported by Gebruk et al. (2000) for the Logatchev site, while $44 \mathrm{~kg} \mathrm{~m}^{-2}$ were estimated for tubeworm assemblages of the Juan de Fuca Ridge (Juniper et al., 1998). These values are, however, highly variable among vent fields even for the same genus. The density of Bathymodiolus azoricus beds at Menez Gwen has been estimated to vary from 400 to $700 \mathrm{ind} \mathrm{m}^{-2}$ (Colaco et al., 1998), corresponding to biomass values ranging between 0.71 and $5.3 \mathrm{~kg} \mathrm{~m}^{-2}$ (wet weight) (Martins et al., 2008). Husson et al. (2017) reported B. azoricus densities ranging from 2232 to 31,630 ind $\mathrm{m}^{-2}$ for Lucky Strike, corresponding to dry weight estimates of 0.1 to $3.1 \mathrm{~kg} \mathrm{~m}^{-2}$ (i.e., 1.5 to $66.8 \mathrm{~kg} \mathrm{~m}^{-2}$ wet weight with shell), while estimating an equivalent to 4.0 dry weight $\mathrm{kg} \mathrm{m}^{-2}$ for Logatchev from Gebruk et al. (2000). Rimicaris exoculata shrimp swarms as dense as 2500 ind $\mathrm{m}^{-2}$ have been described at several vent fields MAR (Van Dover et al., 1988; Copley et al., 1997), and their biomass could reach $4.0 \mathrm{~kg} \mathrm{~m}^{-2}$ if a mean wet weight of $1.6 \mathrm{~g}$ is accounted (RamirezLlodra et al., 2000). Kiwa sp. galatheid crab assemblages of up to 2700 ind $\mathrm{m}^{-2}$ on the Scotia Ridge (Marsh et al., 2012) are likely to reach similar levels of biomass.

Interestingly, these symbioses are found in many vents around the world but their distribution depicts distinct biogeographical provinces. Vent fields with similar properties in two distinct provinces have different symbiotic taxa, dominating their biomass. So far, there are 11 biogeographic provinces identified, including the Arctic and Southern oceans (Moalic et al., 2012; 
Rogers et al., 2012). Conversely, vents with strikingly different geochemistry may host similar taxa within the same province. Within a given province, the key invertebrate taxa may be shared among ultramafic, andesitic and basaltic-hosted vent fields despite striking differences in the "geofuels" contents in the fluids (e.g., on the Mid-Atlantic Ridge R. exoculata or B. azoricus (Desbruyères et al., 2001; Schmidt et al., 2008; Le Bris and Duperron, 2010). Nevertheless, variable densities and size of these aggregations have been attributed to specific biotic and abiotic controls on biomass formation by these species at vent fields hosted in different geological settings (Gebruk et al., 2000; Desbruyères et al., 2001).

The capacity of some invertebrate taxa to host multiple symbionts has been posited as an adaptation to benefit from the diversity of available geofuels. On the mid-Atlantic Ridge, for instance, the relative abundances of methanotrophic and thiotrophic symbionts in B. azoricus at Menez Gwen, Lucky Strike and Rainbow vent fields varies consistently with changes in the chemical energy available from methane and sulfide in their habitat (Duperron et al., 2006; Le Bris and Duperron, 2010). As shown for these species and for the Alviniconcha spp. gastropods from the Lau basin (Beinart et al., 2012), the capacity for thiotrophic symbionts to use hydrogen as an alternative to sulfide further expands the metabolic versatility of the symbiotic association (Petersen et al., 2011). Regional scale differences in symbiont abundances and gene expression in these multiple symbioses of Bathymodiolus mussels and provannid gastropods (Duperron et al., 2006; Dubilier et al., 2008; Duperron, 2010; Beinart et al., 2012) may further reflect flexible pathways in the acquisition of energy. For example, from distinct vent fields from the Eastern Lau basin, Beinart et al. (2012) revealed that four cryptic species of Alviniconcha snails host three symbionts, two types of Gammaproteobacteria and one type of Campylobacteria. Consistently, from North to South along a $\sim 300 \mathrm{~km}$ stretch of vent fields, the campylobacterial symbionts dominated in the northernmost vent fields with the higher end-member $\mathrm{H}_{2}$ and $\mathrm{H}_{2} \mathrm{~S}$ concentrations, while the gammaproteobacterial symbionts dominated in the southernmost vent fields, with decreasing concentrations of both electron donors in the end-member fluids. The striking changes in the association of the host and symbionts were hypothesized to reflect niche adaptation in a geologically complex regional environment.

Experimental studies on the MAR mussel $B$. azoricus further suggested that sulfide-oxidizing and methane-oxidizing symbiont abundances can change over hourly timescales (Halary et al., 2008; Riou et al., 2008) and this capacity was suggested to explain the variable abundance of the two symbionts among individuals from a single chimney, as a response to environmental gradients (Halary et al., 2008). In a recent study of metabolic activity through combined FISH imagery of ribosomal and messenger RNA, Wendeberg et al. (2012) showed that the symbionts modify gene transcription in response to fluctuating concentrations of methane, reduced sulfur compounds and oxygen more rapidly than their population change in abundance, and would thus modulate $\mathrm{CO}_{2}$-fixation rates in response to short-term changes in habitat conditions. How this plasticity relates to the capacity to fix carbon is, however, still largely unconstrained. Estimates of corresponding carbon fixation rates by chemoautotrophic symbionts is restricted by the inability to cultivate them, and has mostly been derived by in vivo experiments on host invertebrates in pressurized aquaria (Childress and Fisher, 1992; Girguis et al., 2000, 2002; Girguis and Childress, 2006; Ponsard et al., 2013; Beinart et al., 2015). Transcriptomic and proteomic studies further shed light on the activity of the metabolic machinery that allows symbionts to optimize energy acquisition and their potential limitation in their natural habitat (Markert et al., 2007; Robidart et al., 2011; Gardebrecht et al., 2012; Sanders et al., 2013; Watsuji et al., 2014). The metatranscriptomic analysis of Sanders et al. (2013) on in situ preserved individuals show distinct sulfur metabolism pathways among the gammaproteobacterial and campylobacterial symbionts, and confirms the capacity of both symbionts to use $\mathrm{H}_{2}$ as an electron donor. Higher expression of hydrogenases consistently correlates with the hydrogen concentration in the end-member fluids and suggests a larger role of this pathway in individuals where the campylobacterial symbiont dominates (Sanders et al., 2013). These authors furthermore observed marked differences in carbon fixation pathways, with the $\mathrm{CBB}$ being dominant in the gammaproteobacterial- and rTCA in the campylobacterial symbiont. In contrast to earlier studies that considered the CBB cycle as the only carbon-fixation pathway, proteome analysis and enzymatic activities revealed that the symbiont of Riftia pachyptila uses the rTCA in combination with the CBB cycle (Markert et al., 2007, 2011), supporting metagenomicbased analyses (Robidart et al., 2008, 2011). Combining the energetically efficient rTCA anaerobic pathway in the low energy hypoxic conditions with the less efficient aerobic CBB pathway in high energy oxygenated conditions, was considered an adaptation to the high temporal variability of in situ conditions (Markert et al., 2007). Gardebrecht et al. (2012) revealed very homogeneous gene expression and enzymatic activity between the symbiont populations of $R$. pachyptila and Tevnia jerichonana co-occurring in a diffuse vent assemblages, but the use of oxygen sensitive rTCA enzymes is favored in T. jerichonana, which is expected to live in the less oxygenated part of the habitat. Despite host regulation, metabolic controls on energy acquisition and $\mathrm{CO}_{2}$-fixation at vent finally appear to be largely influenced by fluctuations and ranges in microhabitat conditions, as shown for the free-living microbes.

\section{HYDROTHERMAL HABITAT CONSTRAINTS ON PRIMARY PRODUCERS}

\section{The Diffuse-Flow Double-Loop Fuelling Distinct Biological Assemblages}

Although the composition of end-member fluids emitted from black smokers are commonly used to compare biodiversity patterns, the flux of electron donors originating from these hightemperature emissions (i.e., $>200^{\circ} \mathrm{C}$ ) remains mostly unavailable to seafloor hydrothermal biota. Buoyant black smoker plumes 
reach temperatures suitable for chemolithotrophs only after significant dilution in abyssal seawater, meters above the seafloor (reviewed by Dick et al., 2013). The cooling of the hydrothermal flow prior its emission on the seabed is a prerequisite for energy transfer to benthic hydrothermal biota, with an upper thermal limit of $\sim 122^{\circ} \mathrm{C}$ (Kashefi, 2003) for prokaryotes and $50-55^{\circ} \mathrm{C}$ for metazoans (Girguis and Lee, 2006; Ravaux et al., 2013). The circulation of seawater through networks of cracks and porous minerals and its interaction with end-member fluids enable heat dissipation and, hence, structure the distribution of habitats for free-living microbes and symbiotic invertebrates. The resulting secondary hydrothermal outflows of low-temperature seawaterdominated mixed fluids, so-called "diffuse flows," are known to dominate the heat budget at vent field scale (Bemis et al., 2012; Mittelstaedt et al., 2012). Ramondenc et al. (2006) estimated that the heat output from diffuse flows could reach ten times that of high-temperature focused flows for an EPR vent field. A similar estimate was obtained at the scale of a large hydrothermal edifice (Tour Eiffel) on the Lucky Strike vent field on the MAR (Mittelstaedt et al., 2012). The supply of electron donors from diffuse flows is also likely to dominate the energy budget available to biota at vent field scale, although attempts to quantify the corresponding chemical fluxes remain rare due to their extensive chemical and thermal variability.

Accordingly, the activity and abundance of chemolithoautotrophs may more closely reflect the chemical properties of these secondary outflows than the properties of conservatively mixed fluids derived from the end-member fluids, which underlie thermodynamics assessments. To examine the factors potentially constraining the hydrothermaly driven chemoautotrophic production, we propose to revisit these properties in the light of the conceptual model of diffuse flows proposed by Lowell et al. (2015) (Figure 2). Often considered as a continuum of end-member fluid dilution in seawater, diffuse-flow fluids rather segregate in two types of flows. A first type of diffuse flows results from the rapid cooling of the high-temperature hydrothermal discharge, hereafter referred as "high-temperature diffuse flows" or "HT-diffuse flows." They are typically represented by secondary outflows through cracks in the wall of black and white smokers or diffusing out of porous minerals. The second type of diffuse flows derives from seawater convection within the basement rocks (e.g., basalt or andesite) with no or limited mixing with the high-temperature discharge whose main conduits are partly insulated by anhydrite precipitated from seawater as temperature increases (Lowell et al., 2015). These low-temperature diffuse flows (LT-diffuse flows) can nevertheless be substantially enriched in volatile compounds $\left(\mathrm{H}_{2} \mathrm{~S}, \mathrm{H}_{2}\right.$, methane) by molecular diffusion and heated by conduction through the mineral layers insulating the high-temperature fluids. These fluid flows are distributed through cracks or holes on the seafloor, such as typically formed on pillow lava, on the walls of large mineral edifices or on inactive deposits, with a wide range of venting temperatures (i.e., a few tens of degree to c.a. $30^{\circ} \mathrm{C}$ above the seawater background) and flow velocities (c.a. $5 \times 10^{-4}$ up to $0.15 \mathrm{~m} \mathrm{~s}^{-1}$ ) (Pruis and Johnson, 2004; Scheirer et al., 2006; Sohn, 2007; Bemis et al., 2012; Barreyre et al., 2014).
The partitioning of biomass-dominant taxa at vent site scale on the East Pacific Rise $9^{\circ} 50^{\prime} \mathrm{N}$ and $13^{\circ} \mathrm{N}$ vent fields illustrates the distinct properties of habitats formed by the two types of flows, with foundation species exclusively associated with hightemperature diffuse flows on chimney walls (e.g., Alvinella spp.) or with low temperature diffuse flow on basalt (e.g., R. pachyptila and Bathymodiolus thermophilus) (Fustec et al., 1987; Shank et al., 1998). On the Juan de Fuca Ridge, Sarrazin et al. (1997) and Sarrazin and Juniper (1999) distinguished five biological assemblages, with alvinellid species similarly dominating HTdiffuse flow habitats on chimney flanks. On north-east Pacific ridges, the endosymbiotic tubeworm Ridgea piscesae with shortfat and long-skinny morphotypes are described in relatively high flow and high sulfide areas on chimneys and low-flow, low temperature, low sulfide on basalt, respectively (Urcuyo et al., 2003). The phenotypic plasticity that enables this species to thrive on habitats associated with the two types of diffuse flows is rather unique in vent species. The presence of $R$. pachyptila, coexisting with an Alvinella pompejana aggregation, on a massive longlived chimney of the East Pacific Rise was instead attributed to distinct types of outflows resulting from entangled plumbing networks within the mineralized structure, as revealed by the distinct properties of the local fluid sources (Le Bris et al., 2006b) (Figure 2). On the MAR, the massive chimney Tour Eiffel also likely encompass the two types of diffuse flows, as illustrated by the patchwork of venting zone on porous substrates, cracks and white smokers with different thermal and chemical ranges, that host distinct taxa assemblages of vent mussels and shrimps (Desbruyères et al., 2000; Le Bris et al., 2000; Desbruyères et al., 2001; Cuvelier et al., 2011; Sarrazin et al., 2014; Husson et al., 2017). In the Eastern Lau basin, Sen et al. (2013) confirmed habitat segregation for symbiont-containing fauna between HTdiffuse flows on anhydrite spires inhabited by Alviniconcha spp. gastropods and mobiles species such as crabs, shrimp and polynoids, and LT-diffuse flows inhabited by Bathymodiolus brevior mussels and Ifremeria nautilei gastropods that occupy similar temperature, sulfide and oxygen ranges on chimney flanks than on solidified lava. The segregation of fauna described on large chimneys and surrounding basalt of the East Scotia Ridge may similarly reflect the two major types of diffuse flows, though temperature and chemical measurements have not been reported to support this conceptual model (Rogers et al., 2012).

On the Juan de Fuca Ridge, Sarrazin and Juniper (1999) reported lower biomasses in habitats associated with the hottest flows $\left(<2 \mathrm{~kg} \mathrm{~m}^{-2}\right)$, compared to low-temperature habitats on the same hydrothermal edifice where $R$. piscesae tubeworm biomasses reached $20 \mathrm{~kg} \mathrm{~m}^{-2}$. However, experimental studies have shown that substrates hosting HT-diffuse flows on chimneys from the $9^{\circ} 50^{\prime} \mathrm{N}$ and $13^{\circ} \mathrm{N}$ vent fields on the East Pacific Rise support the rapid growth of free-living chemolithoautotrophic microbes (Taylor et al., 1999; Alain et al., 2004). Alvinelliddominated communities can reach biomass of about $0.5 \mathrm{~kg} \mathrm{~m}^{-2}$ in 20 to 160 days (Pradillon et al., 2009). In fact, the accumulated biomass does not necessarily reflects the production rate in these habitats, as a substantial fraction of the organic matter produced may be exported as flocs by hydrothermal plumes, sequestered in the mineral edifice as shown for Alvinella spp. 


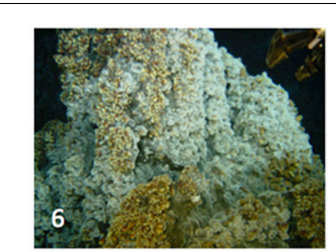

\section{High temperature discharge}

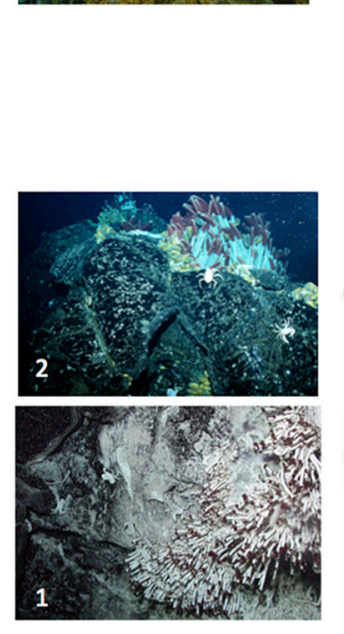

Shallow recharge
HT-1
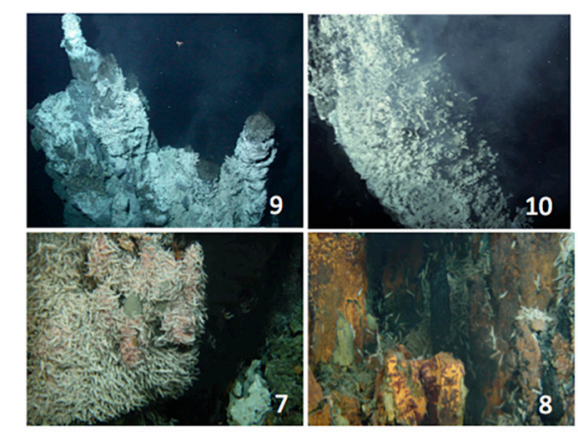

FIGURE 2 | Diffuse-flow types and related seafloor habitats properties (adapted from the double-loop model of Lowell et al., 2015). The blue arrows depict the diffuse fluids issued from the low-temperature recharge convection cell dominated by seawater (LT1 and LT2), the red arrows depict the fluids issued from the convection cell dominated by the end-member fluid discharge (HT1 and HT2). Electron donor contents and temperatures on LT1 and LT2 can have a minor mixing component and variable influences of non-conservative processes such as molecular diffusion of volatiles and heat conduction. HT1 and HT2 electron donor contents and temperatures are dominated by the mixing of the hydrothermal end-member and seawater. Typical assemblages associated with the different diffuse flow types on basalt, hydrothermal edifices of their periphery (1) Tevnia jerichonana and bacterial mat assemblages on fresh lava one year after a volcanic eruption on EPR $9^{\circ} 50^{\prime} \mathrm{N}$, (2) Riftia pachyptila and Bathymodiolus thermophilus mussels in the same area five years after the eruption, (3) B. azoricus beds at Menez Gwen (MAR) surrounding small diffuser structures, (4) B. azoricus beds at Rainbow surrounding small diffusers at the base of a large chimney complex, (5) R. pachyptila surrounding a small diffusing structures covered with Alvinella spp. (EPR13 ${ }^{\circ} \mathrm{N}$ ), (6) B. azoricus beds at Lucky Strike (MAR) on the flank of a large chimney, (7) R. exoculata on the wall of hydrothermal edifices hosting black smoker outflows at TAG and Rainbow (MAR), (8) and (9) Alvinella spp. colonies colonizing the walls of black smokers, one year and five years after an eruption (EPR $\left.9^{\circ} 50^{\prime} \mathrm{N}\right)$.

tubes (Le Bris and Gaill, 2010), or deposited at the base of the chimney under the form of $R$. exoculata shrimp molts (Schmidt et al., 2008). In comparison, areas affected by massive eruptions display extensive LT-diffuse outflows on fresh, highly porous lava and support rapid production and accumulation of biomass over years by foundation species such as R. pachyptila tubeworm and $B$. thermophilus mussel on EPR fields (Fustec et al., 1987; Shank et al., 1998; Scheirer et al., 2006); or the tubeworm R. piscesae on the Juan de Fuca Ridge (Marcus et al., 2009). In comparison, the later stage of an eruption cycle has a reduced seafloor porosity that favor the formation of biomass by longlasting HT-diffuse flow assemblages on mineralized chimneys as represented by vent fauna habitats of EPR $13^{\circ} \mathrm{N}$ where the last eruption is supposed to have occurred more than 29 years ago (Fustec et al., 1987).

\section{Non-conservative Processes Increasing Diffuse-Flow Geochemical Variability}

The physico-chemical properties of diffuse fluids are much more temporally and spatially variable than that of end-member fluids (Koschinsky et al., 2002; Von Damm and Lilley, 2004; Foustoukos et al., 2009; Reeves et al., 2011; Mittelstaedt et al.,
2012; Contreira-Pereira et al., 2013; Ishibashi et al., 2014; Nakamura and Takai, 2014; Nedoncelle et al., 2015). These properties can even vary on semi-diurnal tidal scales (Scheirer et al., 2006; Barreyre et al., 2014) making the assessment of energy flows at vent field scale very difficult. Notwithstanding the type of diffuse flow, the prevalent idea is that vent fluids over a vent field reflect a continuum of mixing ratios of the endmember fluid and seawater that mix conservatively. However, since they are issued from different sub-seafloor fluid networks, several processes leading to non-conservative properties of the mix (i.e., concentrations are not linearly correlated to the seawater-end-member mixing ratio) may imprint their signatures on LT and HT-diffuse flow properties. Mismatch with the conservative dilution model has been repeatedly reported in HT-diffuse flow habitats, as a result of consumption/production of electron donors and conductive heat exchange within the chimney wall. As an example, much higher sulfide concentrations and lower $\mathrm{pH}$ than predicted from the end-member fluid dilution model for a given temperature suggested substantial conductive cooling of HT-diffuse flow fuelling Alvinella spp. colonies (Le Bris et al., 2001, 2003, 2005; Le Bris and Gaill, 2007). Consistently, outflows diffusing the chimney wall beneath polychaete tubes at temperatures ranging 105 to $173^{\circ} \mathrm{C}$ had 
limited seawater contribution despite the temperature being 2 to 3 -fold lower than the end-member fluid temperature (Di MeoSavoie et al., 2004). Complex diffusion and advection processes through porous substrates and cracks of chimney walls are furthermore likely to generate locally distinct temperature, $\mathrm{pH}$, and chemical gradients though selective precipitation processes and consumption of electron donors and acceptors by microbes (Tivey, 2004; McCollom and Amend, 2005).

LT-diffuse flows similarly display variable concentrations in electron donors that reflect extensive sub-seafloor seawater convection in the shallow sub-seafloor, with conductive warming, mixing with a minor fraction of end-member fluid and molecular diffusion through porous anhydrite and sulfide precipitates. Departure from the conservative mixing models was additionally attributed to microbial activities beneath the seafloor within this porous interface (Corliss et al., 1979; Cooper et al., 2000; Von Damm and Lilley, 2004; Waite et al., 2008; Le Bris and Duperron, 2010; Wankel et al., 2011). Accordingly, substantial methane consumption in the sub-surface was documented at Menez Gwen, Lucky Strike and Rainbow on the Mid-Atlantic Ridge where methane is abundant in fluids, reaching up to $60 \%$ of the end-member contribution at the Rainbow vent field (Le Bris and Duperron, 2010). Conversely, on basalt-hosted vent fields like EPR $9^{\circ} 50^{\prime} \mathrm{N}$ where the methane concentration in endmember fluids is low, sub-seafloor methane production can result in higher methane in diffuse fluids than predicted from the dilution of end-members (Lilley et al., 2003; Von Damm and Lilley, 2004). Lowell et al. (2015) yet observed that methane consumption could also take place in the subsurface for certain EPR $9^{\circ} 50^{\prime} \mathrm{N}$ vent sites.

This phenomenon denotes an effective competition for electron donors between sub-seafloor primary producers and those thriving as free-living mats or symbionts on the seafloor (Johnson et al., 1994; Le Bris et al., 2006a; Waite et al., 2008). It should be noted, however, that a large fraction of the electron flux is not utilized by sub-seafloor microorganisms, possibly due to electron acceptor limitation (McNichol et al., 2016). The contribution of the sub-seafloor biosphere to the resources available for the surrounding deep-sea communities lies beyond the scope of this study and is just beginning to be quantitatively addressed (e.g., McNichol et al., 2018). Nevertheless, these microbes also produce electron donors that are exported by fluids and can support additional chemoautotrophic growth on the seafloor, as shown for methane and ammonia (Von Damm and Lilley, 2004). In some cases, even the microbial production of sulfide can be significant, as in Lost City fluids where anaerobic methane oxidation is coupled to sulfate reduction (Brazelton et al., 2006).

\section{Electron Donor Availability in the Thermal Niches of Symbiotic Invertebrates}

The boundary layer where diffuse fluids mix with seawater above the seafloor shapes the limits of the habitable space for different types of vent invertebrate harboring chemoautotrophic symbionts (Van Dover, 2000; Desbruyères et al., 2001; Fisher et al., 2007). The cooler end of the associated thermocline, at which point the temperature reaches that of background seawater, expands no further than a few decimeters above the local outflow (and typically less than a few meters horizontally, following cracks or porous substrates) and fluctuates both vertically and horizontally (Johnson et al., 1988a,b; Scheirer et al., 2006). Johnson et al. (1988a) first described the chemical gradients across this interface by using a submersible in situ chemical analyzer. Within tubeworm assemblages colonizing LT-diffuse flow habitats of Rose Garden (Galapagos Spreading Center), steep variations in $\mathrm{H}_{2} \mathrm{~S}, \mathrm{Fe}^{\mathrm{II}}, \mathrm{Mn}^{\mathrm{II}}, \mathrm{CH}_{4}$ exhibited quasilinear relationships with silica, a conservative tracer of the source fluid dilution in seawater and were also linearly correlated with temperature. Further studies confirmed the conservative mixing of the local fluid source as the main driver of these gradients in habitats of $R$. pachyptila and B. thermophilus on the East Pacific Rise (Le Bris et al., 2006a). Biological consumption in dense clumps and mussel beds can nevertheless generate large deviations from this conservative mixing model as revealed by the comparison of gradients before and after the local fauna had been removed (Johnson et al., 1988a,b, 1994; Le Bris et al., 2006a).

The ratios of $\mathrm{H}_{2} \mathrm{~S} / \mathrm{T}, \mathrm{CH}_{4} / \mathrm{T}$ and $\mathrm{Fe}^{\mathrm{II}} / \mathrm{T}$ can hence be primarily considered as conserved variables across a vent site, independent of the degree of dilution of the source fluid fueling secondary flows (Le Bris et al., 2006a,b; Le Bris and Duperron, 2010; Lowell et al., 2015) (Table 1 and Supplementary Table S1). $\mathrm{H}_{2} \mathrm{~S} / \mathrm{T}$, in particular, has been widely used to explore differences in the habitats of foundation species within a vent field or among vent fields that hold the imprint of the geological setting (Le Bris et al., 2006a,b; Podowski et al., 2010; Gartman et al., 2011). On the Eastern Lau Basin, for instance, Gartman et al. (2011) reported a decrease in the $\mathrm{H}_{2} \mathrm{~S} / \mathrm{T}$ ratio in diffuse-flow habitats from the northern basalt-hosted vent fields (Kilo Moana and TCaldera) to the southern ones ( $\mathrm{ABE}$ and $\mathrm{Tu}$ 'i). Even though these $\mathrm{H}_{2} \mathrm{~S} / \mathrm{T}$ ratios are much lower than those of end-member fluids on these vent fields (e.g., 5.6-7.0 versus 16.5-19.9 at Kilo Moana; 1.92.1 versus 6.7-8.7 at Tu'i (Mottl et al., 2011)), the decrease is consistent with a greater proportion of andesite in the rocks hosting the hydrothermal circulation closer to the subduction zone to the South.

Numerous studies of vent habitats also used this proxy to compare the available energy for distinct assemblages of biomassdominant invertebrates over space and time, particularly on the unstable Galapagos Spreading Center and East Pacific Rise vent fields (Johnson et al., 1988a,b; Nees et al., 2008; Moore et al., 2009; Mullineaux et al., 2012) (Table 1). Within different vent sites of the EPR $9^{\circ} 50^{\prime} \mathrm{N}$ vent field, very similar $\mathrm{H}_{2} \mathrm{~S} / \mathrm{T}$ ratios were measured among assemblages of tubeworms, mixed tubeworm-mussel aggregations or mussel beds suggesting that the extent of dilution rather than the properties of the fluid source fueling them was the discriminating factor among the two colonists (Le Bris et al., 2006a). In contrast, distinct $\mathrm{H}_{2} \mathrm{~S} / \mathrm{T}$ ratios were observed between adjacent areas of HT-diffuse and LT-diffuse flows within a meter from each other, reflected by different invertebrate colonies (Alvinella spp. and R. pachyptila) (Luther et al., 2001; Le Bris et al., 2003, 2006b). Similarly, 
TABLE 1 | Ratios of sulfide to temperature anomalies (with respect to background seawater) characterizing diffuse flow habitats at deep-sea hydrothermal vents.

\begin{tabular}{|c|c|c|c|c|}
\hline \multirow{2}{*}{$\begin{array}{l}H_{2} S / \Delta T \\
\left(\mu M^{\circ} C^{-1}\right)\end{array}$} & \multirow{2}{*}{$\begin{array}{l}\text { All studied hydrothermal } \\
\text { vent fields }\end{array}$} & \multicolumn{2}{|c|}{ Mid-Ocean Ridges } & \multirow{2}{*}{$\begin{array}{l}\text { Arcs and back-arc } \\
\text { spreading centers }\end{array}$} \\
\hline & & Excluding post-eruption & $<3 y$ post-eruption & \\
\hline Mean & 12.0 & 9.2 & 21.7 & 11.8 \\
\hline Max & 90.5 & 54.3 & 90.5 & 52.9 \\
\hline Min & 0 & 0 & 0.0 & 0.0 \\
\hline Median & 7.8 & 5.8 & 20.4 & 6.1 \\
\hline Q1 & 3.1 & 2.6 & 11.7 & 1.8 \\
\hline Q3 & 16.7 & 11.8 & 29.5 & 15.0 \\
\hline
\end{tabular}

adjacent flows with different $\mathrm{H}_{2} \mathrm{~S} / \mathrm{T}$ ratios have been described on large edifices of the Mid-Atlantic Ridge, as for instance on segregated patches of Bresiliid shrimps and B. azoricus mussels on the Tour Eiffel edifice of Lucky Strike vent field (Le Bris et al., 2000; De Busserolles et al., 2009). Another example can be given from the Lau Basin where significantly higher ratios were found in the habitat of the gastropod Alviniconcha spp., as compared to the other dominant gastropod species I. nautilei on hydrothermal edifices from 3 vent fields (Podowski et al., 2010; Gartman et al., 2011). Interestingly, the $\mathrm{H}_{2} \mathrm{~S} / \mathrm{T}$ ratio in the habitats of these two species are not conserved between vent fields but the areas with the highest $\mathrm{H}_{2} \mathrm{~S} / \mathrm{T}$ ratios were occupied by Alviniconcha spp. suggesting a competition for habitat (Gartman et al., 2011).

Significant temporal variations in the $\mathrm{H}_{2} \mathrm{~S} / \mathrm{T}$ ratio were reported as well. From 2004 to 2005, in the years before the eruption at $9^{\circ} 50^{\prime} \mathrm{N}$ EPR, Nees et al. (2008) described an increase in the $\mathrm{H}_{2} \mathrm{~S} / \mathrm{T}$ ratio for the tubeworm habitat at Tica, one of the few sites that remained active after the eruption. In 2007, this ratio remained similar to its pre-eruption value in 2005. Marcus et al. (2009) described a decrease in the $\mathrm{H}_{2} \mathrm{~S} / \mathrm{T}$ ratios over three years combined with a decrease in the temperature and sulfide content of new vents formed after an eruption at Axial Volcano on the Juan de Fuca Ridge. In the Lau Basin, four vent fields exhibited a change in the $\mathrm{H}_{2} \mathrm{~S} / \mathrm{T}$ ratio from 2006 to 2009 (Gartman et al., 2011), with an $\mathrm{H}_{2} \mathrm{~S} / \mathrm{T}$ ratio increasing for the three northern sites. In comparison at the southernmost site, Tu'i Malila, $\mathrm{H}_{2} \mathrm{~S} / \mathrm{T}$ varied by less than $10 \%$ over the same period.

\section{Environmental Factors Limiting Energy Harnessing Processes by Symbiotic Fauna}

Rocky vent habitats do not have a narrow well-defined redoxcline, as established for sedimentary environments. Since advection and mixing are the primary mechanisms supplying both electron donors and acceptors at the seafloor, oxygen often coexists with sulfide and other electron donors in the cooler region of the mixing boundary layer (Johnson et al., 1988a,b; Schmidt et al., 2008; Moore et al., 2009; Zielinski et al., 2011). As the seawater contribution decreases in the mixed layer, the oxygen content proportionally decreases. In situ measurements furthermore show that oxygen is depleted by biological and abiotic processes and only remains available in the periphery of the mixing interface. The temperature limit for oxygen availability in the surrounding of tubeworms and mussels on the East Pacific Rise and Galapagos Spreading Center was found to be no more than 11-12 ${ }^{\circ} \mathrm{C}$ (Corliss et al., 1979; Johnson et al., 1988b, 1994; Moore et al., 2009). A large portion of the tubeworm habitat, where temperature can reach $30^{\circ} \mathrm{C}$ at the base of tubes, is thus devoid of oxygen. At Logatchev on the Mid-Atlantic Ridge, Zielinski et al. (2011) established a similar thermal boundary for oxygen in mussel beds, despite a much higher oxygen concentration in the cooler end of the thermal gradient corresponding to the Atlantic deep-sea water mass. The $\mathrm{O}_{2} / \mathrm{T}$ ratio (defined by the temperature and oxygen content of abyssal waters, on one side, and the maximum temperature of the oxycline on the other side of the gradient) therefore appears as another discriminating variable of vent habitats (Johnson et al., 1988a,b; Luther et al., 2008; Nees et al., 2008; Moore et al., 2009; Zielinski et al., 2011). In comparison to LT-diffuse flows, vigorously mixing of HT-diffuse flow fluids with seawater could enhance oxygen availability in the mixing zone. Oxygen was reported to be present at temperatures up to $30^{\circ} \mathrm{C}$ in the surroundings of Rimicaris shrimp assemblages on the Rainbow vent field fueled by fluids that emanate from the walls of large edifices (Schmidt et al., 2008). On the flank of chimneys in the Lau basin, oxygen did not decrease below $60 \mu \mathrm{M}$ at $22^{\circ} \mathrm{C}$, the maximum temperature of the Alviniconcha spp. habitat, suggesting that this environment is also more oxygenated than LT-diffuse flows in the area (Podowski et al., 2010). However, this situation cannot be generalized for chimney flank habitats on the East Pacific Rise, as the A. pompejana environment is strongly depleted in oxygen, with concentrations lying below the detection limit of $5 \mu \mathrm{M}$ at $13^{\circ} \mathrm{C}$ (Di Meo-Savoie et al., 2004). The differences in oxygen availability in habitats are thus only partly explained by the type of diffuse venting, by biological oxygen consumption and by the oxygen content in deep-sea waters. The later widely varies across ocean basins and depths (Boyer et al., 2013), with abyssal waters being noticeably much more oxygenated over the Mid-Atlantic Ridge vent fields (Le Bris et al., 2000; Schmidt et al., 2008; Zielinski et al., 2011; Perner et al., 2013; Sarrazin et al., 2015) than on the East Pacific Rise (Johnson et al., 1988a; Luther et al., 2001; Nees et al., 2008; Moore et al., 2009).

Despite most vent invertebrates have respiratory and metabolic adaptations that enable them to thrive in relative hypoxia or intermittent anoxia (Hourdez and Lallier, 2007), oxygen is likely to be a strong driver of primary production by symbiotic fauna. Thermodynamic models confirm that the maximum available energy (per kilogram of mixed fluids) is set by the availability of oxygen in the thermal niche of symbiotic 
species on the Mid-Atlantic Ridge (Schmidt et al., 2008; Le Bris and Duperron, 2010). The most energetic conditions for the $R$. exoculata epibionts at Rainbow and TAG or B. azoricus at Menez Gwen, Lucky Strike and Rainbow lie in the 15$25^{\circ} \mathrm{C}$ range. Experimental studies in high-pressure aquaria furthermore identified oxygen uptake as a limiting factor for Riftia growth (Girguis and Childress, 2006; Childress and Girguis, 2011). In situ measurements confirmed that oxygen availability is effectively limiting in the microenvironment of their assemblages on the East Pacific Rise (Johnson et al., 1994; Moore et al., 2009) and suggested that oxygen availability might act as a discriminative factor between $T$. jerichonana and $R$. pachyptila, the two tubeworm species coexisting in vent habitats 2 years after a volcanic eruption (Moore et al., 2009). Since, endosymbiotic invertebrates with $\mathrm{O}_{2}$-binding hemoglobins have the capacity to bind oxygen and transfer it to their symbionts, they may take advantage of oxygen and sulfide fluctuations to meet their energetic requirements (Childress and Fisher, 1992; Johnson et al., 1994). More generally, tidal modulations of the mixing plume induced by bottom currents indeed generate alternative oxic-anoxic conditions in diffuse flow habitats and impose variable abiotic constraints on biomassdominant species (Scheirer et al., 2006; Mittelstaedt et al., 2012; Barreyre et al., 2014; Nedoncelle et al., 2015; Sarrazin et al., 2015). So far, such constraints have not been systematically explored, but first attempts to relate the $B$. thermophilus growth rate to tidal cycling confirmed strong relationships between growth and the hydrodynamic regime (Nedoncelle et al., 2015). $\mathrm{pH}$, oxygen and sulfide fluctuations modulated by the tidal regime were shown to favor shell growth, while more stable chemical conditions at higher hydrothermal flow appear less suitable (Nedoncelle et al., 2015).

Other abiotic factors that characterize chemical speciation in the diffuse flow-seawater mixing boundary layer might also influence the capacity of chemolithoautotroph to meet their energetic requirements. The proportion of free sulfide forms (i.e., $\mathrm{H}_{2} \mathrm{~S}$ and $\mathrm{HS}^{-}$) drives the capacity of endosymbiont hosts to transport sulfide through gill membranes (Goffredi et al., 1997). The exclusion of Riftia from some HT-diffuse flow areas inhabited by alvinellids was thus attributed to the formation of iron sulfide complexes or nanopolymers (Luther et al., 2001). $\mathrm{Fe} / \mathrm{H}_{2} \mathrm{~S}$ in diffuse flows and the relative proportion of free sulfide is, however, largely variable among HT-diffuse flows, even within the same vent field (Shank et al., 1998; Le Bris et al., 2003; Von Damm and Lilley, 2004; Le Bris and Gaill, 2007; Le Bris and Duperron, 2010). The $\mathrm{pH}$ of LT-diffuse flows that generally lies in the moderately acidic to neutral range (e.g., 6-7, Sarradin et al., 1998; Le Bris et al., 2001; Le Bris et al., 2006a; Schmidt et al., 2008) is another potentially significant factor discriminating suitable habitats for vent species. $\mathrm{pH}$ in vent habitats decreases exponentially from bottom seawater to the substrate, typically over a few centimeters (Le Bris et al., 2001, 2003, 2006a). Conductive cooling further enhances this constraint by generating steep $\mathrm{pH}$ gradients (up to 3 units) at the surface of chimney walls (Le Bris et al., 2001; Le Bris and Gaill, 2007). While the $\mathrm{H}_{2} \mathrm{~S} / \mathrm{HS}^{-}$ratio is directly governed by $\mathrm{pH}$, more toxic conditions are expected when $\mathrm{pH}$ decreases below
6.5 (i.e., below $\mathrm{pKa}^{\mathrm{H} 2 \mathrm{~S}}$ in seawater at salinity of $35,2500 \mathrm{~m}$ and c.a. $25^{\circ} \mathrm{C}$ ) (Le Bris et al., 2003, 2006b). Mussels are additionally sensitive to constraints on the formation of their calcified shell with particularly extreme conditions expected on ABA where end-member fluids display $\mathrm{pH}$ lower than 1.0 (Tunnicliffe et al., 2009).

The abiotic oxidation of electron donors is not considered to be limiting for the energy transfer to vent biota, even when oxygen is abundant. Based on the laboratory works of Millero et al. (1987), Johnson et al. (1988a) calculated a lifetime $>100 \mathrm{~h}$ for sulfide in oxygenated seawater at the Galapagos Spreading Center. On the same empirical basis, Gartman et al. (2011) estimated an abiotic sulfide oxidation rate as low as 2 to 9 $10^{-4} \mu \mathrm{mol} \mathrm{l}^{-1} \mathrm{~min}^{-1}$ in diffuse flow habitats of the Lau basin. High-pressure aquaria experiments confirmed that the microbial symbionts of vent gastropods enhance sulfide oxidation by three or more orders of magnitude (Luther et al., 2012). Whether this result can be extrapolated to all vent symbioses still need to be tested. The catalysis of abiotic sulfide oxidation by $\mathrm{Fe}^{\mathrm{II}}$ (Zhang and Millero, 1993) was not considered in these kinetic assessments, although it may enhance the competition between microbes and the abiotic oxidation of sulfide. Similarly, the degree of abiotic oxidation of hydrogen by oxygen could be modulated according to the composition of the fluid and venting type. In comparison, the abiotic oxidation of iron is rapid and autocatalytic and the competition between abiotic and microbial iron oxidation is a well-known constraint for iron oxidizers, which only thrive in microaerophilic conditions (Emerson and Moyer, 2002).

\section{THE TEMPORAL DRIVERS OF ORGANIC CARBON PRODUCTION AT THE VENT FIELD SCALE}

\section{Rise and Decline of Biomass-Dominant Primary Producers After Volcanic Eruptions}

Shaped by magmatic and tectonic activity cycles, the instability of venting was noticed as soon as the first discovered vent fields on the Galapagos Spreading Center and East Pacific Rise were revisited 1-2 years later (Fustec et al., 1987; Hessler et al., 1988). In the last 40 years, volcanic eruptions have been reported at few vent fields on both MOR and ABA (Rubin et al., 2012 for review). Only four of them have been monitored annually during the recolonization process: Cleft segment, Co-Axial and Axial Volcano seamounts on the Juan de Fuca Ridge (Tunnicliffe et al., 1997; Tsurumi and Tunnicliffe, 2001; Marcus et al., 2009) and $9^{\circ} 50^{\prime} \mathrm{N}$ on the East Pacific Rise (Haymon et al., 1993; Lutz et al., 1994; Shank et al., 1998; Mullineaux et al., 2012). The monitoring of these areas revealed that large changes in both endmember fluids and diffuse flow composition associate with the colonization of new habitats formed by the massive lava flows that eradicated previously resident communities. Synthesizing field observations and experimental studies, Mullineaux et al. (2018) emphasized the complex interaction processes driving the 
dynamics of these communities, which include both regional controls on larval dispersal and local controls on settlement and growth by habitat conditions. In the metapopulation framework proposed by these authors, the turnover of species dominating the primary production over successive recolonization stages is not only driven by their capacity to outcompete for habitat and resources (i.e., electron donors and acceptors) but also by their dispersal ability. Poor competitors with large dispersal capacity may hence take advantage of new habitats to settle and grow, rapidly forming large biomasses, before being outcompeted by late colonizers. In addition, species that strongly influence the physico-chemical gradients, increasing the stability of their habitat, are likely to persist longer as dominant primary producers. Such marked transitions in the succession of colonists, from free-living microbes to the symbiotic species that dominate pioneer and mature communities, have been repeatedly described and help setting the basis for a primary producer succession model on representative ecosystem timescales (Figure 3).

On the two fast-spreading ridges, the first year following an eruption is marked by a peak in sulfide (up to $50 \mathrm{mmol} \mathrm{kg}^{-1}$ ),

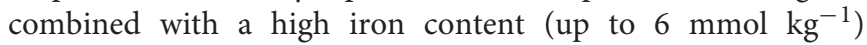
of end-member fluids, denoting the direct interaction of dike and seawater (Butterfield et al., 1997; Von Damm et al., 1997; Von Damm and Lilley, 2004; Pester et al., 2014). On the Main Endeavor Field (JdFR), Lilley et al. (2003) highlighted a steep rise of the concentrations of sulfide and hydrogen in end-member fluids attributed to the magmatic event. Yet, the most remarkable characteristics of hydrothermal habitats in the months following the eruption is that LT-diffuse flows hosting microbial biofilms spread over large surface of the cooling lava (Tunnicliffe et al., 1997; Shank et al., 1998; Gulmann et al., 2015). So far, very limited chemical data are available for these early LT-diffuse flows but the high $\mathrm{H}_{2} \mathrm{~S} / \mathrm{T}$ reported for such microbial habitats one year after for the last eruption on EPR $9^{\circ} 50^{\prime} \mathrm{N}$ exceeds that of mature LT-diffuse flows (Mullineaux et al., 2012; O’Brien et al., 2015). Early post-eruption conditions are coupled with high colonization rates of microbial biofilm formation, as revealed by the formation of sulfur mats on new basalt surfaces exposed to diffuse flows within days (Gulmann et al., 2015; O’Brien et al., 2015). Pioneer colonist communities are composed almost exclusively of Campylobacteria such as Arcobacter and Sulfurovum. The diversity of diffuse-flow vent microbial communities evolves over monthly scales (from a few days to 9 months) to a more diverse assemblage including Gamma-, Delta-proteobacteria and Bacteroidetes (Gulmann et al., 2015). Carbon fixation by these early colonizers remain largely unconstrained owing to the wide diversity of, both, microbial metabolic capabilities and the spatial and temporal variability of in situ niche conditions (Sievert and Vetriani, 2012; Campbell et al., 2013).

One-two years after the opening of new habitats on fresh lava, few pioneer species of symbiont-bearing invertebrates dominated the biomass of diffuse-flow habitats and chemosynthetic primary production (Tunnicliffe et al., 1997; Shank et al.,

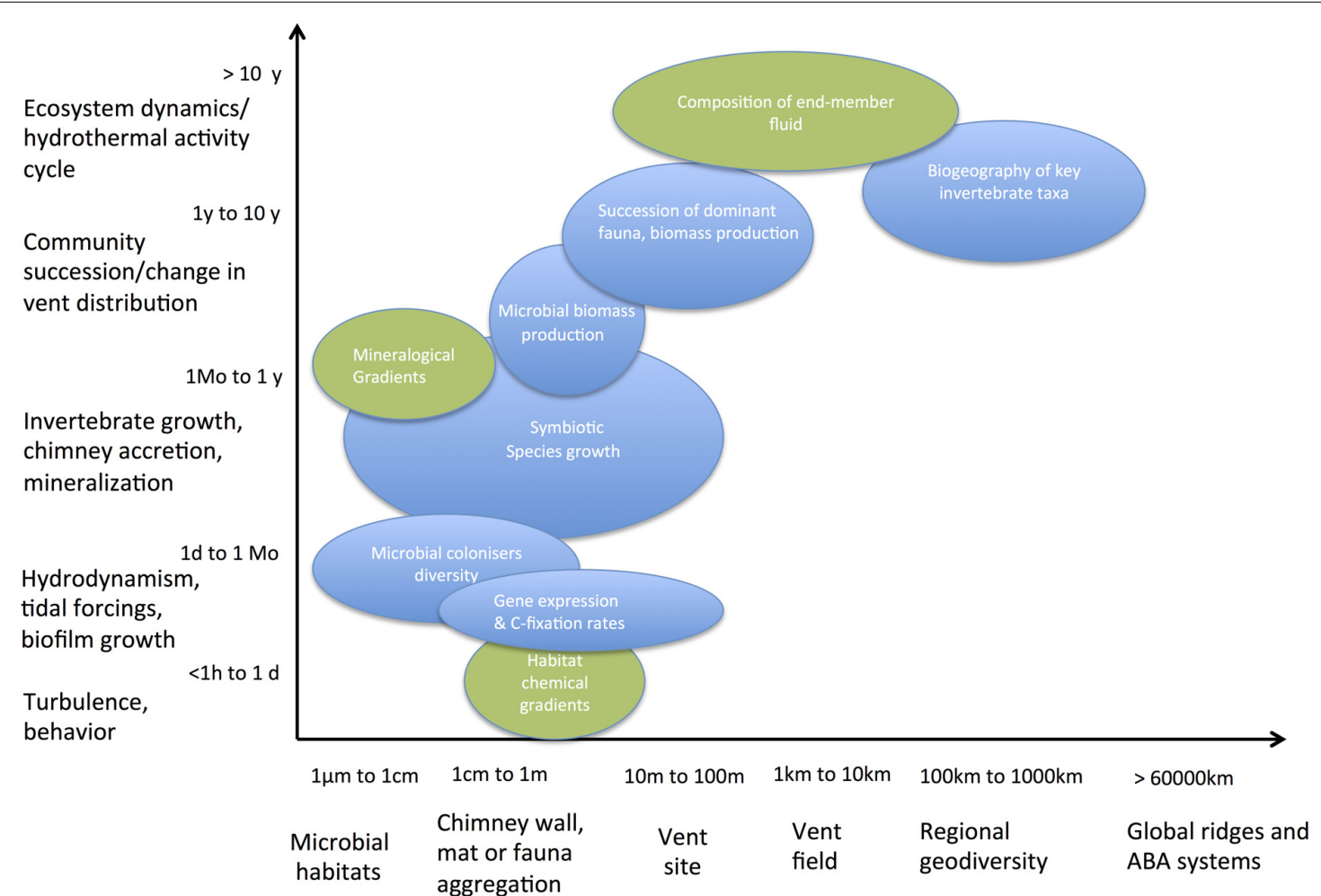

FIGURE 3 | Typical temporal and spatial scales of investigation of key processes driving the chemoautotrophic productivity in deep-sea hydrothermal vent systems, which need to be integrated to address the productivity of these ecosystems. 
1998; Mullineaux et al., 2010, 2012). These early assemblages transitioned to mature assemblages after about 3 years with the decline of first colonizers and on-set of symbiotic species that dominated pre-eruption assemblages. As diverse communities of invertebrates build 3D-assemblages in the immediate periphery of diffusing vents, free-living microbial communities can colonize new habitats formed at their surface (Govenar and Fisher, 2007; Martins et al., 2009; Cuvelier et al., 2012) benefiting abundant grazer populations (e.g., polychaetes and gastropods) (Marcus et al., 2009). Though it is unknown how much freeliving chemolithoautotrophic microbes contribute to biomass production in mature assemblages, strictly autotrophic organisms related to members of the genera Thioclava, Thiomicrospira, and Halothiobacillus have been identified in tubeworm and mussel assemblages at $9^{\circ} 50^{\prime} \mathrm{N}$ EPR (Lutz et al., 2008). The contribution of free-living microbes to the production of organic carbon might be even more important in the LT-diffuse flow habitats, where thick microbial mats formed within only a few weeks on experimental substrates deployed on chimney walls occupied by alvinellids (Taylor et al., 1999; Alain et al., 2004). Alvinella worms particularly create energy-rich habitats inside and around their tube, acting as ecosystem engineers promoting free-living chemolithoautotroph growth (Le Bris et al., 2005; Le Bris and Gaill, 2007, 2010).

Optimal conditions for symbiotic invertebrate growth may represent a narrow temporal window in the life cycle of a vent on fast-spreading ridges. The pioneer tubeworm species, T. jerichonana, experience severe oxygen limitations in post-eruption habitats (Nees et al., 2008). R. pachyptila, as well, encounter strong environmental constraints to $\mathrm{H}_{2} \mathrm{~S}$ and bicarbonate uptake for its symbionts (Childress and Fisher, 1992; Girguis and Childress, 2006). The decline of tubeworm assemblages within respectively two to three years after an eruption has been associated with a substantial reduction of venting activity and lower $\mathrm{H}_{2} \mathrm{~S} / \mathrm{T}$ in LT-diffuse flows (Shank et al., 1998). Similarly, Marcus et al. (2009) described the decline of the sulfide to heat ratio in fluids associated with Ridgeia piscesae assemblages at eight diffuse flow vents on the Axial volcano (JdFR) in the three years following a volcanic eruption. The local depletion of sulfide in dense aggregations of endosymbiotic invertebrates, as revealed by nonlinear relationships with temperature, furthermore limits the energy available for their symbionts (Johnson et al., 1988a, 1994; Le Bris et al., 2006a). Clearance experiments confirmed that consumption is particularly important in B. thermophilus mussel beds of the east Pacific (Johnson et al., 1994; Le Bris et al., 2006a; Lutz et al., 2008) and can locally lead to the complete removal of sulfide in large assemblages. More generally, much lower sulfideto-temperature ratios than expected from conservative mixing of the outflow denote the efficiency of Bathymodiolus spp. in assimilating the sulfide flux available in their microenvironment (Johnson et al., 1988a; Le Bris et al., 2006a; Contreira-Pereira et al., 2013; Nedoncelle et al., 2015).

Ultimately, the rapid decline of the endosymbiotic populations has been related to an increase in the iron to sulfide ratio in diffuse flows (Fustec et al., 1987; Tunnicliffe et al., 1997; Shank et al., 1998), while end-member fluids transition from vapor-type to brine-type end-member fluids with the progressive cooling and phase separation associated with the deepening of the magmatic lens (Butterfield et al., 1997; Von Damm et al., 1997; Yücel and Luther, 2013). The formation of iron-sulfide complexes that prevents tubeworms from assimilating free sulfide (e.g., $\mathrm{H}_{2} \mathrm{~S}$ and $\mathrm{HS}^{-}$) that is likely to limit the growth and, ultimately, the survival of tubeworms (Luther et al., 2001; Le Bris et al., 2006a,b). Using thermodynamic calculations based on end-member fluid properties, Hentscher and Bach (2012) furthermore suggested that the late metal-rich stage would favor free-living microbes using sulfide precipitates and dissolved iron as electron donors over thiotrophic symbioses. This geochemical sequence occurs on time-scales of 3 to 10 years for the east-Pacific sites surveyed at EPR $9^{\circ} 50^{\prime} \mathrm{N}$ in 1991-2005 and 2006-2014 (German and Seyfried, 2014), but could expand over much longer scales on slow-spreading ridges.

Conversely, ectosymbiotic species are less sensitive to change in fluid composition. A. pompejana, for instance, dominates the biomass of producers on chimney walls with a large range in ironto-sulfide ratios (Le Bris et al., 2003; Le Bris and Gaill, 2007). The capacity of alvinellids to sustain their thiotrophic ectosymbionts in iron rich habitats could rely on specific adaptations allowing the ventilation of tubes by oxygenated seawater and the diffusion of free sulfide through tube walls, hence buffering chemical conditions inside their tubes (Di Meo-Savoie et al., 2004; Le Bris et al., 2005).

Although they also contribute to this biomass, meiofauna species harboring symbionts are unlikely to make a major contribution to this production, except perhaps as early colonists during early post-eruption stages or in declining and inactive vent habitats (Zeppilli et al., 2018 and reference therein). Very little is known, however, about the temporal variability of the density and biomass of these species, which respond differently to changing habitat conditions than the large biomass-dominant taxa (Gollner et al., 2010, 2015).

\section{Production of Chemosynthetic Resources on Stable and Inactive Hydrothermal Settings}

Among the few areas monitored over the last decades on MOR, several vent fields exhibit a remarkable chemical stability of the end-member fluids (German and Von Damm, 2004), which is consistent with a much longer geological periodicity in volcanic or tectonic instabilities. Vent fields with stable end-member fluids compositions have been studied on both fast-spreading (EPR $21^{\circ} \mathrm{S}$, Guaymas basin, JdFR South Cleft segment), and slow-spreading ridges (Rainbow, TAG) (Schmidt et al., 2007; Charlou et al., 2010; German and Seyfried, 2014). Yet, the temporal cyclicity of hydrothermal activity and related chemosynthetic productivity remains poorly constrained on slow spreading ridges, where long period of quiescence may still sustain high macro- and megafauna densities. The relative stability of mussel populations studied over 14 years on the Tour Eiffel edifice (Lucky Strike, MAR) (Cuvelier et al., 2011) indicates that populations can be relatively stable. If we assume that predation and population turnover 
is limited, then a totally different model than for the fastspreading ridge is emerging with more stable productivity rates over decadal and longer timescales (Martins et al., 2008).

At geological time scales, volcanic eruptions and their influence on the iron to sulfide ratio in fluids still impose strong limits on primary producers shaping the suitability of habitat at regional scale (Desbruyères et al., 2001; Lartaud et al., 2011). On slow-spreading ridges, however, B. azoricus and $B$. puteoserpentis mussels from ultramafic-hosted vent fields can use methane or hydrogen when free sulfide is unavailable due to high iron concentrations in fluids, at late stages of the vent field cycle, as at Rainbow or Logatchev on the Mid-Atlantic Ridge (Le Bris and Duperron, 2010). According to Petersen et al. (2011), the ability to use hydrogen could be common in vent symbioses and that even at basaltic sites low hydrogen production could sustain B. puteoserpentis mussels. Perner et al. (2007) and Perner et al. (2013) further described the capacity of this species to form dense beds in either sulfide-rich or hydrogen-rich and methane-rich lowflow conditions. By revealing functional similarity in trophic networks from different Mid-Atlantic Ridge vent fields hosting B. azoricus assemblages, Portail et al. (2018) suggested that the trophic flexibility of these symbioses would take advantage of relatively stable conditions, independently of the nature of available geofuels. The factors that limit the production of biomass by these invertebrates, and the free-living microbial communities that grow within the biogenic habitat they form, however, rely on complex biotic interactions that needs to be accounted for in addition to abiotic constraints (Perner et al., 2013).

The temporal variability of end-member fluids and conditions of related habitats are much less known on ABA where tectonic and volcanic instability is expected to largely influence hydrothermal activity, especially at sites undergoing continuous eruptions (Embley et al., 2006). Very few vent fields have been repeatedly sampled to document this variability (Herzig et al., 1998 for Lau Basin, for Mariana Arc, Seewald et al., 2015 for Manus Basin, Ishibashi et al., 2014 for the Okinawa Trough), yet the dynamics of ecosystem response to environmental variability that just begin to be studied denoted unexpected stability in the structure of some edifices and the vent-associated assemblages that colonize them (Sen et al., 2014; Du Preez and Fisher, 2018).

The chemosynthetic energy budget of hydrothermal settings also encompassed mineral deposits and fluid circulations hosted on relict vent fields. Electron donors stored in the form of precipitated metal sulfides remain available to specialized chemolithoautotrophs, potentially contributing to the hydrothermal energy budget for deep-sea communities (Figure 3). As these inactive systems are considered for deepsea mining activities (Loka Bharathi and Shanta Nair, 2005; Levin et al., 2009; Van Dover, 2011), the number of studies investigating the microbial communities colonizing inactive hydrothermal settings has increased (e.g., Kato et al., 2010; Sylvan et al., 2012; Li et al., 2017; Kato et al., 2018). While these studies have revealed the presence of chemolithoautotrophs, assessing their activities and contribution to overall carbon production remains a challenge. Compared to active systems, the involved activities are likely to be low, but due to the large volume of inactive deposits, their contributions could be significant over longer time scales. Furthermore, even in the absence of high-temperature activity, specific hydrothermal biotopes around fissures in the basement indicated that massive sulfide deposits host low-temperature emissions that might persist over geological timescales as described on slow-and ultra-slow spreading ridges (Rona et al., 1996; Pedersen et al., 2010). Lalou et al. (1989) first examined the mineralogy and chronology of the fossil hydrothermal sulfide deposits on the Galapagos Spreading Centre near $85^{\circ} 00 \mathrm{~W}$. The sulfide deposits amounted to some 100000 tons and consisted of chimney-like formations, hydrothermal crusts and ore bodies. Dating of minerals established the presence of two hydrothermal activity periods, the most recent one about 8000 years ago. Another well-studied example is the Trans-Atlantic Geotraverse (TAG) hydrothermal mound on the Mid-Atlantic Ridge, consisting of active low- and high-temperature zones as well as a number of relict deposits (Rona et al., 1996). Radiometric dating of sulfides from the TAG mound indicates that the hydrothermal activity started at this site episodically for over 40000-50000 years, every 4000 to 6000 years over the past 20000 years and is currently in an active phase (Lalou et al., 1993, 1998).

Mineralogical observations support the idea that microorganisms could be involved in the oxidation of sulfide minerals (Al-Hanbali and Holm, 2002). Microprobe investigations on the TAG minerals revealed carbon-based structures with the morphology of half-spheroids that are 2 to $3 \mu \mathrm{m}$ in diameter and are mostly arranged in the form of clusters and long thread-like cellular masses that resemble single-celled microorganisms. Precipitation of iron oxides in the immediate vicinity of these microfossils are enriched in both $\mathrm{C}$ and $\mathrm{P}$, in contrast to distal Fe oxides produced by the abiotic oxidation of mineral sulfides, further suggesting that this phase is of microbial origin. Hydrothermal deposits would thus have the potential to sustain both chemoautotrophy and chemoheterotrophy. Iron oxidizers not only play a role in mineral sulfide alteration, they also expand the carbon fixation capacity of vent systems long after hydrothermal circulation has ceased (Glynn et al., 2006; Li et al., 2017). Chemoautotrophic iron oxidizers have been described from rocks and sediment samples from inactive areas (Emerson and Moyer, 2002; Edwards et al., 2003) More recently, Wang et al. (2017) revealed new insights into the operational mechanism of the microbial communities associated with Pacmanus and Desmos hydrothermal sediments. Gammaproteobacteria were the most abundant bacterial populations. The autotrophic prokaryotes probably fixed $\mathrm{CO}_{2}$ via the four major pathways, i.e., Calvin-Benson-Bassham cycle, reductive acetyl-CoA cycle, rTCA cycle, and 3-hydroxypropionate/4-hydroxybutyrate cycle.

Such processes may also be significant in young oceanic crust ridge flanks, along tectonic cracks and faults, where $\mathrm{Fe}$ Si-Mn hydrothermal deposits form. Benjamin and Haymon (2006) described hydrothermal mineral deposits and fossil biota 
from a young $(0.1 \mathrm{Ma})$ abyssal hill on the flank of the fastspreading East Pacific Rise attributed to pulsed hydrothermal flow and tectonic tapping of axial heat and fluids. Clusters of empty worm tubes further indicated that fluid flow waned only recently (Haymon et al., 2005). Since heat flow data indicate that most hydrothermal heat loss from ocean lithosphere occurs on the flanks of the MOR, such off-axis vents might be more widespread than observed from occasional surveys with submersibles.

\section{CONCLUSION}

Beyond changes in energy availability, as reflected in the temporal evolution of vent fluids geochemistry, we have now a clearer picture of various abiotic and biological controls exerted on the activities of primary producers and biomass formation in vent habitats. Changes in seafloor permeability over space and time create discontinuities in the sub-seafloor plumbing system, with two convection cells that result in distinct diffuse-flow types, the first one being dominated by the dilution of the hydrothermal high-temperature fluids with seawater, while the second is predominantly based on heated seawater incorporating reduced compounds by diffusion. The steep variation in the $\mathrm{H}_{2} \mathrm{~S} / \mathrm{T}$ ratios of diffuse fluids that can occur within short distances on large edifices denote marked differences in the properties of two types of flows. This partitioning makes temperature alone unsuitable for comparing the available energy for chemolithoautotrophs among vent assemblages. This review particularly draws attention to the fact that distinct sets of geochemical constraints on energy transfer capacities and competition for resources between sub-seafloor and seafloor communities are likely to occur for the two types of flows and should be accounted for.

Critical gaps in the current understanding of ecological and metabolic regulation that drives the efficiency of the energy transfer from the geothermal source to ecosystems are also highlighted. Together with the end-member fluid geochemical evolution over time, changes in seafloor and chimney wall porosity govern the available electron donor pools in the different thermal ranges on the seafloor and set the limits for the succession of dominant primary-producers. Ultimately, volcanic and seismic instabilities drive the productivity of the ecosystem over time as they control the hydrothermal energy flow and the relative contribution of the two convection cells. The temporal evolution of interactions between vent organisms and their environment, however, remains poorly documented with the exception of a few seafloor observatories or longterm study sites. The interactions between key players of chemosynthetic carbon-fixation and their symbiotic invertebrate hosts in response to the spatial and temporal heterogeneity of environmental conditions has largely improved thanks to the development of large-scale seafloor observatories, on one end, and molecular and analytical tools on the other end. Despite rapid improvements, the capacity to describe environmental conditions at scales relevant to carbon-fixation processes from sampling (minerals and fluids) to in situ measurement of dissolved electron donors and acceptors and associated key parameters (i.e., temperature, $\mathrm{pH}$ ) still faces strong challenges.

There is a need for the development of a database of growth efficiencies of dominant microbes under realistic habitat conditions, accounting for the habitat-building role of dominant invertebrate species. These data should be better constrained by investigating natural communities at conditions contributing to a better understanding of interactions within microbial consortia characterizing chemosynthetic systems. Downscaling (single cell, metagenomics and transcriptomic) and upscaling (enlarging global inventories to allow metadata analyses of relationships between habitats and biomass-dominant species) will offer opportunities to better analyze the drivers of microbial carbon fixation in vent habitats.

Current advances in underwater technologies, tending to be more cost effective and miniaturized, and recognition of the need for a global coordinated effort in deep-ocean observation are paving the way for a new stage in the investigation of hydrothermal systems in relation to the activity-cycle of a vent field. Combined in vivo experiments with in situ experiments and observations still represent the next frontier to improve quantitative modeling. Expanding these approaches beyond the areas where large seafloor infrastructures have been established represents a major challenge if we are to assess the importance of hydrothermal energy transfer from regional settings to the global MORs and arc-back-arc systems.

\section{AUTHOR CONTRIBUTIONS}

NLB designed the review and realized figures. NLB and MY prepared the Supplementary Table S1. NLB, MY, AD, SMS, PL, and PG wrote the manuscript.

\section{FUNDING}

NLB has been supported as part of the Chair "Biodiversity, extreme marine environment and global change" UPMC, CNRS and Foundation Total. PL was funded by CSIR (Council of Scientific and Industrial Research) with Emeritus Scientist Fellowship (Scheme Nos: 31/26(209)/2011 EMR-I and $21 /(086) / 11 / E M R-I I)$. AD was supported by CSIR (Council of Scientific and Industrial Research) with research associateship and SERB (Science and Engineering Research Board) with young scientist fellowship. This material is based in part upon work supported by the National Science Foundation under Grant Numbers NSF-1542506 and NSF OCE-1635365 to PG and NSF OCE-1136727, NSF OCE-1559198 to SMS, and OCE-0938349 and OCE-1243377 to the Scientific Committee on Oceanic Research (SCOR). SMS was also supported by The WHOI Investment in Science Fund and a WHOI Tenured Associate Scientist Award. Any opinions, findings, and conclusions or recommendations expressed in this material are those of the author(s) and do not necessarily reflect the views of the National Science Foundation. Credit for Figure 1. 
Valerie Domien (CNRS, Oceanological Observatory of Banyuls) and NLB.

\section{ACKNOWLEDGMENTS}

This review has been initiated from the works of the SCORInterRidge working group "hydrothermal energy transfer and the ocean carbon cycle" lead by NLB and C. R. German, with PL, SMS, and PG also being members. Discussions during three meetings of the working group and contributions to

\section{REFERENCES}

Adams, D. K., McGillicuddy, D. J., Zamudio, L., Thurnherr, A. M., Liang, X., Rouxel, O., et al. (2011). Surface-generated Mesoscale eddies transport deep-sea products from hydrothermal vents. Science 332, 580-583. doi: 10.1126/science. 1201066

Alain, K., Zbinden, M., Le Bris, N., Lesongeur, F., Quérellou, J., Gaill, F., et al. (2004). Early steps in microbial colonization processes at deep-sea hydrothermal vents. Environ. Microbiol. 6, 227-241. doi: 10.1111/j.1462-2920. 2003.00557.x

Al-Hanbali, H. S., and Holm, N. G. (2002). Evidence for fossilized subsurface microbial communities at the TAG hydrothermal mound. Geomicrobiol. J. 19, 429-438. doi: 10.1080/01490450290098522

Allen, D. E., and Seyfried, W. E. (2004). Serpentinization and heat generation: constraints from lost city and rainbow hydrothermal systems 11 Associate editor: J. C. Alt. Geochim. Cosmochim. Acta 68, 1347-1354. doi: 10.1016/j.gca. 2003.09.003

Amend, J. P., Edwards, K. J., and Lyons, T. W. (eds). (2004). Sulfur Biogeochemistry: Past and Present. Boulder, CO: Geological Society of America.

Amend, J. P., McCollom, T. M., Hentscher, M., and Bach, W. (2011). Catabolic and anabolic energy for chemolithoautotrophs in deep-sea hydrothermal systems hosted in different rock types. Geochim. Cosmochim. Acta 75, 5736-5748. doi: 10.1016/j.gca.2011.07.041

Bach, W., Edwards, K. J., Hayes, J. M., Sievert, S., Huber, J. A., and Sogin, M. L. (2006). Energy in the dark: fuel for life in the deep ocean and beyond. Eos Trans. Am. Geophys. Union 87, 73-78. doi: 10.1029/2006EO070002

Baker, E. T., Resing, J. A., Haymon, R. M., Tunnicliffe, V., Lavelle, J. W., Martinez, F., et al. (2016). How many vent fields? New estimates of vent field populations on ocean ridges from precise mapping of hydrothermal discharge locations. Earth Planet. Sci. Lett. 449, 186-196. doi: 10.1016/j.epsl.2016.05.031

Barreyre, T., Escartín, J., Sohn, R. A., Cannat, M., Ballu, V., and Crawford, W. C. (2014). Temporal variability and tidal modulation of hydrothermal exit-fluid temperatures at the Lucky Strike deep-sea vent field, Mid-Atlantic Ridge: MAR vent-field temperature monitoring. J. Geophys. Res. Solid Earth 119, 2543-2566. doi: 10.1002/2013JB010478

Beaulieu, S. E., Baker, E. T., and German, C. R. (2015). Where are the undiscovered hydrothermal vents on oceanic spreading ridges? Deep Sea Res. Part II Top. Stud. Oceanogr. 121, 202-212. doi: 10.1016/j.dsr2.2015.05.001

Beaulieu, S. E., Baker, E. T., German, C. R., and Maffei, A. (2013). An authoritative global database for active submarine hydrothermal vent fields: global vents database. Geochem. Geophys. Geosyst. 14, 4892-4905. doi: 10.1002/ 2013GC004998

Beinart, R. A., Gartman, A., Sanders, J. G., Luther, G. W., and Girguis, P. R. (2015). The uptake and excretion of partially oxidized sulfur expands the repertoire of energy resources metabolized by hydrothermal vent symbioses. Proc. R. Soc. B Biol. Sci. 282:20142811. doi: 10.1098/rspb.2014.2811

Beinart, R. A., Sanders, J. G., Faure, B., Sylva, S. P., Lee, R. W., Becker, E. L., et al. (2012). Evidence for the role of endosymbionts in regional-scale habitat partitioning by hydrothermal vent symbioses. Proc. Natl. Acad. Sci. U.S.A. 109, E3241-E3250. doi: 10.1073/pnas.1202690109

Bell, J. B., Woulds, C., and Oevelen, D. V. (2017). Hydrothermal activity, functional diversity and chemoautotrophy are major drivers of seafloor carbon cycling. Sci. Rep. 7:12025. doi: 10.1038/s41598-017-12291-w the conference sessions organized by the WG members have supported the foundation of the article.

\section{SUPPLEMENTARY MATERIAL}

The Supplementary Material for this article can be found online at: https://www.frontiersin.org/articles/10.3389/fmars. 2018.00531/full\#supplementary-material

TABLE S1 | $\mathrm{H}_{2} \mathrm{~S}$ concentration and temperature of diffuse fluids.

Bemis, K., Lowell, R., and Farough, A. (2012). Diffuse flow on and around hydrothermal vents at mid-ocean ridges. Oceanography 25, 182-191. doi: 10. 5670/oceanog.2012.16

Benjamin, S. B., and Haymon, R. M. (2006). Hydrothermal mineral deposits and fossil biota from a young $(0.1 \mathrm{Ma})$ abyssal hill on the flank of the fast spreading East Pacific Rise: evidence for pulsed hydrothermal flow and tectonic tapping of axial heat and fluids: EPR Mineral Deposits. Geochem. Geophys. Geosyst. 7, 1-26. doi: 10.1029/2005GC001011

Bennett, S. A., Achterberg, E. P., Connelly, D. P., Statham, P. J., Fones, G. R., and German, C. R. (2008). The distribution and stabilisation of dissolved Fe in deep-sea hydrothermal plumes. Earth Planet. Sci. Lett. 270, 157-167. doi: 10.1016/j.epsl.2008.01.048

Berg, I. A. (2011). Ecological aspects of the distribution of different autotrophic $\mathrm{CO}_{2}$ fixation pathways. Appl. Environ. Microbiol. 77, 1925-1936. doi: 10.1128/ AEM.02473-10

Böhnke, S., and Perner, M. (2017). Unraveling Rubis CO form I and form II regulation in an uncultured organism from a deep-sea hydrothermal vent via metagenomic and mutagenesis studies. Front. Microbiol. 8:1303. doi: 10.3389/ fmicb.2017.01303

Boschen, R. E., Rowden, A. A., Clark, M. R., and Gardner, J. P. A. (2013). Mining of deep-sea seafloor massive sulfides: a review of the deposits, their benthic communities, impacts from mining, regulatory frameworks and management strategies. Ocean Coast. Manage. 84, 54-67. doi: 10.1016/j.ocecoaman.2013.07. 005

Boyer, T. P., Antonov, J. I., Baranova, O. K., Garcia, H. E., Johnson, D. R., Mishonov, A. V., et al. (2013). World Ocean Database 2013. Silver Spring, MD: NOAA Printing Officce.

Brazelton, W. J., Schrenk, M. O., Kelley, D. S., and Baross, J. A. (2006). Methane- and sulfur-metabolizing microbial communities dominate the lost city hydrothermal field ecosystem. Appl. Environ. Microbiol. 72, 6257-6270. doi: 10.1128/AEM.00574-06

Butterfield, D. A., Jonasson, I. R., Massoth, G. J., Feely, R. A., Roe, K. K., Embley, R. E., et al. (1997). Seafloor eruptions and evolution of hydrothermal fluid chemistry. Philos. Trans. R. Soc. A Math. Phys. Eng. Sci. 355, 369-386. doi: 10.1098/rsta.1997.0013

Butterfield, D. A., Nakamura, K. I., Takano, B., Lilley, M. D., Lupton, J. E., Resing, J. A., et al. (2011). High SO2 flux, sulfur accumulation, and gas fractionation at an erupting submarine volcano. Geology 39, 803-806. doi: 10.1130/G31901.1

Campbell, B. J., Engel, A. S., Porter, M. L., and Takai, K. (2006). The versatile $\varepsilon-$ proteobacteria: key players in sulphidic habitats. Nat. Rev. Microbiol. 4, 458-468. doi: 10.1038/nrmicro1414

Campbell, B. J., Polson, S. W., Zeigler Allen, L., Williamson, S. J., Lee, C. K., and Wommack, K. E. (2013). Diffuse flow environments within basalt- and sediment-based hydrothermal vent ecosystems harbor specialized microbial communities. Front. Microbiol. 4:182. doi: 10.3389/fmicb.2013.00182

Cannat, M., Fontaine, F., and Escartín, J. (2010). "Serpentinization and associated hydrogen and methane fluxes at slow spreading ridges," in Geophysical Monograph Series, eds P. A. Rona, C. W. Devey, J. Dyment, and B. J. Murton (Washington, DC: American Geophysical Union), 241-264.

Charlou, J., Donval, J., Fouquet, Y., Jean-Baptiste, P., and Holm, N. (2002). Geochemistry of high $\mathrm{H}_{2}$ and $\mathrm{CH}_{4}$ vent fluids issuing from ultramafic rocks at the Rainbow hydrothermal field ( $36^{\circ} 14^{\prime} \mathrm{N}$, MAR). Chem. Geol. 191, 345-359. doi: 10.1016/S0009-2541(02)00134-1 
Charlou, J. L., Donval, J. P., Konn, C., Ondréas, H., Fouquet, Y., Jean-Baptiste, P., et al. (2010). "High production and fluxes of $\mathrm{H} 2$ and $\mathrm{CH}_{4}$ and evidence of abiotic hydrocarbon synthesis by serpentinization in ultramafic-hosted hydrothermal systems on the Mid-Atlantic Ridge," in Geophysical Monograph Series, eds P. A. Rona, C. W. Devey, J. Dyment, and B. J. Murton (Washington, DC: American Geophysical Union), 265-296. doi: 10.1029/2008GM 000752

Childress, J. J., and Fisher, C. R. (1992). The biology of hydrothermal vent animals: physiology, biochemistry, and autotrophic symbioses. Oceanogr. Mar. Biol. Annu. Rev. 30, 337-441.

Childress, J. J., and Girguis, P. R. (2011). The metabolic demands of endosymbiotic chemoautotrophic metabolism on host physiological capacities. J. Exp. Biol. 214, 312-325. doi: 10.1242/jeb.049023

Colaco, A., Desbruyeİres, D., Comtet, T., and Alayse, A. M. (1998). Ecology of the Menez-Gwen hydrothermal vent field. Cah. Biol. Mar. 39, 237-240. doi: 10.1016/j.margen.2015.09.001

Collins, P. C., Croot, P., Carlsson, J., Colaço, A., Grehan, A., Hyeong, K., et al. (2013). A primer for the environmental impact assessment of mining at seafloor massive sulfide deposits. Mar. Policy 42, 198-209. doi: 10.1016/j.marpol.2013. 01.020

Connelly, D. P., Copley, J. T., Murton, B. J., Stansfield, K., Tyler, P. A., German, C. R., et al. (2012). Hydrothermal vent fields and chemosynthetic biota on the world's deepest seafloor spreading centre. Nat. Commun. 3:620. doi: 10.1038/ ncomms 1636

Contreira-Pereira, L., Yücel, M., Omanovic, D., Brulport, J.-P., and Le Bris, N. (2013). Compact autonomous voltammetric sensor for sulfide monitoring in deep sea vent habitats. Deep Sea Res. Part I Oceanogr. Res. Pap. 80, 47-57. doi: 10.1016/j.dsr.2013.05.014

Cooper, M. J., Elderfield, H., and Schultz, A. (2000). Diffuse hydrothermal fluids from lucky strike hydrothermal vent field: evidence for a shallow conductively heated system. J. Geophys. Res. Solid Earth 105, 19369-19375. doi: 10.1029/ 2000JB900138

Copley, J. T. P., Tyler, P. A., Murton, B. J., and Van Dover, C. L. (1997). Spatial and interannual variation in the faunal distribution at Broken Spur vent field $\left(29^{\circ} \mathrm{N}\right.$. Mid-Atlantic Ridge). Mar. Biol. 129, 723-733. doi: 10.1007/s002270050215

Corliss, J. B., Dymond, J., Gordon, L. I., Edmond, J. M., von Herzen, R. P., Ballard, R. D., et al. (1979). Submarine thermal springs on the Galápagos rift. Science 203, 1073-1083. doi: 10.1126/science.203.4385.1073

Cuvelier, D., de Busserolles, F., Lavaud, R., Floc'h, E., Fabri, M.-C., Sarradin, P.M., et al. (2012). Biological data extraction from imagery - How far can we go? A case study from the Mid-Atlantic Ridge. Mar. Environ. Res. 82, 15-27. doi: 10.1016/j.marenvres.2012.09.001

Cuvelier, D., Sarrazin, J., Colaço, A., Copley, J. T., Glover, A. G., Tyler, P. A., et al. (2011). Community dynamics over 14 years at the Eiffel Tower hydrothermal edifice on the Mid-Atlantic Ridge. Limnol. Oceanogr. 56, 1624-1640. doi: 10. 4319/lo.2011.56.5.1624

Das, A., Fernandes, C. E. G., Naik, S. S., Nagender Nath, B., Suresh, I., Mascarenhas-Pereira, M. B. L., et al. (2011). Bacterial response to contrasting sediment geochemistry in the Central Indian Basin: bacteria and contrasting geochemistry in the CIB. Sedimentology 58, 756-784. doi: 10.1111/j.1365-3091. 2010.01183.x

De Busserolles, F., Sarrazin, J., Gauthier, O., Gélinas, Y., Fabri, M. C., Sarradin, P. M., et al. (2009). Are spatial variations in the diets of hydrothermal fauna linked to local environmental conditions? Deep Sea Res. Part II Top. Stud. Oceanogr. 56, 1649-1664. doi: 10.1016/j.dsr2.2009.05.011

Deckert, G., Warren, P. V., Gaasterland, T., Young, W. G., Lenox, A. L., Graham, D. E., et al. (1998). The complete genome of the hyperthermophilic bacterium Aquifex aeolicus. Nature 392, 353-358. doi: 10.1038/32831

Desbruyères, D., Almeida, A., Biscoito, M., Comtet, T., Khripounoff, A., Le Bris, N., et al. (2000). "A review of the distribution of hydrothermal vent communities along the northern Mid-Atlantic Ridge: dispersal vs. environmental controls," in Island, Ocean and Deep-Sea Biology, eds M. B. Jones, J. M. N. Azevedo, A. I. Neto, A. C. Costa, and A. M. Frias Martins (Berlin: Springer), 201-216. doi: 10.1007/978-94-017-1982-7_19

Desbruyères, D., Biscoito, M., Caprais, J.-C., Colaço, A., Comtet, T., Crassous, P., et al. (2001). Variations in deep-sea hydrothermal vent communities on the Mid-Atlantic Ridge near the Azores plateau. Deep Sea Res. Part I Oceanogr. Res. Pap. 48, 1325-1346. doi: 10.1016/S0967-0637(00)00083-2
Di Meo-Savoie, C. A., Luther, G. W., and Cary, S. C. (2004). Physicochemical characterization of the microhabitat of the epibionts associated with Alvinella pompejana, a hydrothermal vent annelid. Geochim. Cosmochim. Acta 68, 20552066. doi: 10.1016/j.gca.2003.10.039

Dick, G. J., Anantharaman, K., Baker, B. J., Li, M., Reed, D. C., and Sheik, C. S. (2013). The microbiology of deep-sea hydrothermal vent plumes: ecological and biogeographic linkages to seafloor and water column habitats. Front. Microbiol. 4:124. doi: 10.3389/fmicb.2013.00124

Du Preez, C., and Fisher, C. R. (2018). Long-term stability of back-arc basin hydrothermal vents. Front. Mar. Sci. 5:54. doi: 10.3389/fmars.2018.00054

Dubilier, N., Bergin, C., and Lott, C. (2008). Symbiotic diversity in marine animals: the art of harnessing chemosynthesis. Nat. Rev. Microbiol. 6, 725-740. doi: $10.1038 /$ nrmicro1992

Duperron, S. (2010). "The diversity of deep-sea mussels and their bacterial symbioses," in The Vent and Seep Biota, ed. S. Kiel (Dordrecht: Springer), $137-167$.

Duperron, S., Bergin, C., Zielinski, F., Blazejak, A., Pernthaler, A., McKiness, Z. P., et al. (2006). A dual symbiosis shared by two mussel species, Bathymodiolus azoricus and Bathymodiolus puteoserpentis (Bivalvia: Mytilidae), from hydrothermal vents along the northern Mid-Atlantic Ridge. Environ. Microbiol. 8, 1441-1447. doi: 10.1111/j.1462-2920.2006.01038.x

Edwards, K. J., Bach, W., and McCollom, T. M. (2005). Geomicrobiology in oceanography: microbe-mineral interactions at and below the seafloor. Trends Microbiol. 13, 449-456. doi: 10.1016/j.tim.2005.07.005

Edwards, K. J., Rogers, D. R., Wirsen, C. O., and McCollom, T. M. (2003). Isolation and characterization of novel psychrophilic, neutrophilic, $\mathrm{Fe}$ Oxidizing, chemolithoautotrophic - and -Proteobacteria from the Deep Sea. Appl. Environ. Microbiol. 69, 2906-2913. doi: 10.1128/AEM.69.5.2906-2913. 2003

Embley, R. W., Chadwick, W. W., Baker, E. T., Butterfield, D. A., Resing, J. A., de Ronde, C. E. J., et al. (2006). Long-term eruptive activity at a submarine arc volcano. Nature 441, 494-497. doi: 10.1038/nature04762

Emerson, D., and Moyer, C. L. (2002). Neutrophilic Fe-Oxidizing bacteria are abundant at the loihi seamount hydrothermal vents and play a major role in fe oxide deposition. Appl. Environ. Microbiol. 68, 3085-3093. doi: 10.1128/AEM. 68.6.3085-3093.2002

Fisher, C. R., Takai, K., and Le Bris, N. (2007). Hydrothermal vent ecosystems. Oceanography 20, 14-23. doi: 10.5670/oceanog.2007.75

Fitzsimmons, J. N., Boyle, E. A., and Jenkins, W. J. (2014). Distal transport of dissolved hydrothermal iron in the deep South Pacific Ocean. Proc. Natl. Acad. Sci. U.S.A. 111, 16654-16661. doi: 10.1073/pnas.1418778111

Foustoukos, D. I., Pester, N. J., Ding, K., and Seyfried, W. E. (2009). Dissolved carbon species in associated diffuse and focused flow hydrothermal vents at the main endeavour field, Juan de Fuca Ridge: phase equilibria and kinetic constraints. Geochem. Geophys. Geosyst. 10, 1-13. doi: 10.1029/2009GC002472

Fustec, A., Desbruyeİres, D., and Juniper, K. (1987). Deep-Sea hydrothermal vent communities at $13^{\circ} \mathrm{N}$ on the east pacific rise: microdistribution and temporal variations. Biol. Oceanogr. 4, 121-164.

Gallant, R. M., and Von Damm, K. L. (2006). Geochemical controls on hydrothermal fluids from the Kairei and Edmond Vent Fields, $23^{\circ}-25^{\circ} \mathrm{S}$, central Indian Ridge: controls on hydrothermal fluids. Geochem. Geophys. Geosyst. 7, 1-24. doi: 10.1029/2005GC001067

Gamo, T., Chiba, H., Yamanaka, T., Okudaira, T., Hashimoto, J., Tsuchida, S., et al. (2001). Chemical characteristics of newly discovered black smoker fluids and associated hydrothermal plumes at the Rodriguez Triple Junction, Central Indian Ridge. Earth Planet. Sci. Lett. 193, 371-379. doi: 10.1016/S0012$821 \mathrm{X}(01) 005118$

Gardebrecht, A., Markert, S., Sievert, S. M., Felbeck, H., Thürmer, A., Albrecht, D., et al. (2012). Physiological homogeneity among the endosymbionts of Riftia pachyptila and Tevnia jerichonana revealed by proteogenomics. ISME J. 6, 766-776. doi: 10.1038/ismej.2011.137

Gartman, A., Yücel, M., and Luther, G. W. (2014). “An introduction to the major chemical components released from hydrothermal vents," in Reference Module in Earth Systems and Environmental Sciences, ed. S. Elias (New York, NY: Elsevier).

Gartman, A., Yücel, M., Madison, A. S., Chu, D. W., Ma, S., Janzen, C. P., et al. (2011). Sulfide oxidation across diffuse flow zones of hydrothermal vents. Aquat. Geochem. 17, 583-601. doi: 10.1007/s10498-011-9136-1 
Gebruk, A. V., Chevaldonné, P., Shank, T., Lutz, R. A., and Vrijenhoek, R. C. (2000). Deep-sea hydrothermal vent communities of the Logatchev area $\left(14^{\circ} 45^{\prime} \mathrm{N}\right.$, Mid-Atlantic Ridge): diverse biotopes and high biomass. J. Mar. Biol. Assoc. U.K. 80, 383-393. doi: 10.1017/S0025315499002088

German, C. R., Ramirez-Llodra, E., Baker, M. C., Tyler, P. A., and the CHESS Scientific Steering Committee (2011). Deep-water chemosynthetic ecosystem research during the census of marine life decade and beyond: a proposed deep-ocean road map. PLoS One 6:e23259. doi: 10.1371/journal.pone.0023259

German, C. R., and Seyfried, W. E. (2014). "Hydrothermal processes,"," in Treatise on Geochemistry, eds H. D. Holland and K. K. Turekian (New York, NY: Elsevier), 191-233. doi: 10.1016/B978-0-08-095975-7.00607-0

German, C. R., and Von Damm, K. L. (2004). "“Hydrothermal processes,", in Treatise on Geochemistry, eds H. D. Holland and K. K. Turekian (New York, NY: Elsevier), 181-222.

Girguis, P. R., and Childress, J. J. (2006). Metabolite uptake, stoichiometry and chemoautotrophic function of the hydrothermal vent tubeworm Riftia pachyptila: responses to environmental variations in substrate concentrations and temperature. J. Exp. Biol. 209, 3516-3528. doi: 10.1242/jeb.02404

Girguis, P. R., Childress, J. J., Freytag, J. K., Klose, K., and Stuber, R. (2002). Effects of metabolite uptake on proton-equivalent elimination by two species of deep-sea Vestimentiferan tubeworm, Riftia pachyptila and Lamellibrachia luymesi: proton elimination is a necessary adaptation to sulfide-oxidizing chemoautotrophic symbionts. J. Exp. Biol. 205, 3055-3066.

Girguis, P. R., and Lee, R. (2006). Thermal preference and tolerance of Alvinellids. Science 312, 231-231. doi: 10.1126/science.1125286

Girguis, P. R., Lee, R. W., Desaulniers, N., Childress, J. J., Pospesel, M., Felbeck, H., et al. (2000). Fate of nitrate acquired by the tubeworm Riftia pachyptila. Appl. Environ. Microbiol. 66, 2783-2790. doi: 10.1128/AEM.66.7.2783-2790. 2000

Glover, A. G., Gooday, A. J., Bailey, D. M., Billett, D. S. M., Chevaldonné, P., and Colaço, A. (2010). "Temporal change in deep-sea benthic ecosystems," in Advances in Marine Biology, eds J. H. S. Blaxter and B. Douglas (New York, NY: Elsevier), 1-95.

Glynn, S., Mills, R., Palmer, M., Pancost, R., Severmann, S., and Boyce, A. (2006). The role of prokaryotes in supergene alteration of submarine hydrothermal sulfides. Earth Planet. Sci. Lett. 244, 170-185. doi: 10.1016/j.epsl.2006.01.065

Goffredi, S. K., Childress, J. J., Desaulniers, N. T., and Lallier, F. J. (1997). Sulfide acquisition by the vent worm Riftia pachyptila appears to be via uptake of HS-, rather than H2S. J. Exp. Biol 200, 2609-2616.

Gollner, S., Govenar, B., Fisher, C., and Bright, M. (2015). Size matters at deep-sea hydrothermal vents: different diversity and habitat fidelity patterns of meio- and macrofauna. Mar. Ecol. Prog. Ser. 520, 57-66. doi: 10.3354/meps11078

Gollner, S., Kaiser, S., Menzel, L., Jones, D. O. B., Brown, A., Mestre, N. C., et al. (2017). Resilience of benthic deep-sea fauna to mining activities. Mar. Environ. Res. 129, 76-101. doi: 10.1016/j.marenvres.2017.04.010

Gollner, S., Riemer, B., Martínez Arbizu, P., Le Bris, N., and Bright, M. (2010). Diversity of Meiofauna from the $9^{\circ} 50^{\prime} \mathrm{N}$ East Pacific Rise across a Gradient of hydrothermal fluid emissions. PLoS One 5:e12321. doi: 10.1371/journal.pone. 0012321

Govenar, B., and Fisher, C. R. (2007). Experimental evidence of habitat provision by aggregations of Riftia pachyptila at hydrothermal vents on the East Pacific Rise. Mar. Ecol. 28, 3-14. doi: 10.1111/j.1439-0485.2007.00148.x

Govenar, B., Le Bris, N., Gollner, S., Glanville, J., Aperghis, A. B., Hourdez, S., et al. (2005). Epifaunal community structure associated with Riftia pachyptila aggregations in chemically different hydrothermal vent habitats. Mar. Ecol. Prog. Ser. 305, 67-77. doi: 10.3354/meps305067

Gulmann, L. K., Beaulieu, S. E., Shank, T. M., Ding, K., Seyfried, W. E., and Sievert, S. M. (2015). Bacterial diversity and successional patterns during biofilm formation on freshly exposed basalt surfaces at diffuse-flow deep-sea vents. Front. Microbiol. 6:901. doi: 10.3389/fmicb.2015.00901

Halary, S., Riou, V., Gaill, F., Boudier, T., and Duperron, S. (2008). 3D FISH for the quantification of methane- and sulphur-oxidizing endosymbionts in bacteriocytes of the hydrothermal vent mussel Bathymodiolus azoricus. ISME J. 2, 284-292. doi: 10.1038/ismej.2008.3

Halfar, J., and Fujita, R. M. (2007). Ecology: danger of deep-sea mining. Science 316, 987-987. doi: 10.1126/science.1138289

Hawkes, J. A., Connelly, D. P., Gledhill, M., and Achterberg, E. P. (2013). The stabilisation and transportation of dissolved iron from high temperature hydrothermal vent systems. Earth Planet. Sci. Lett. 375, 280-290. doi: 10.1016/ j.epsl.2013.05.047

Haymon, R. M., Fornari, D. J., Von Damm, K. L., Lilley, M. D., Perfit, M. R., Edmond, J. M., et al. (1993). Volcanic eruption of the mid-ocean ridge along the East Pacific Rise crest at $9^{\circ} 45-52^{\prime} \mathrm{N}$ : direct submersible observations of seafloor phenomena associated with an eruption event in April, 1991. Earth Planet. Sci. Lett. 119, 85-101. doi: 10.1016/0012-821X(93)90008-W

Haymon, R. M., Macdonald, K. C., Benjamin, S. B., and Ehrhardt, C. J. (2005). Manifestations of hydrothermal discharge from young abyssal hills on the fast-spreading East Pacific Rise flank. Geology 33, 153-156. doi: 10.1130/G2 1058.1

He, Z., Gentry, T. J., Schadt, C. W., Wu, L., Liebich, J., Chong, S. C., et al. (2007). GeoChip: a comprehensive microarray for investigating biogeochemical, ecological and environmental processes. ISME J. 1, 67-77. doi: 10.1038/ismej. 2007.2

Hentscher, M., and Bach, W. (2012). Geochemically induced shifts in catabolic energy yields explain past ecological changes of diffuse vents in the East Pacific Rise $9^{\circ} 50^{\prime} \mathrm{N}$ area. Geochem. Trans. 13:2. doi: 10.1186/1467-4866-13-2

Herzig, P. M., Hannington, M. D., and Arribas, A. Jr. (1998). Sulfur isotopic composition of hydrothermal precipitates from the Lau back-arc: implications for magmatic contributions to seafloor hydrothermal systems. Mineralium Deposita 33, 226-237. doi: 10.1007/s001260050143

Hessler, R. R., Smithey, W. M., Boudrias, M. A., Keller, C. H., Lutz, R. A., and Childress, J. J. (1988). Temporal change in megafauna at the rose garden hydrothermal vent (Galapagos Rift; eastern tropical Pacific). Deep Sea Res. Part A Oceanogr. Res. Pap. 35, 1681-1709. doi: 10.1016/0198-0149(88)90044-1

Hodgkinson, M. R. S., Webber, A. P., Roberts, S., Mills, R. A., Connelly, D. P., and Murton, B. J. (2015). Talc-dominated seafloor deposits reveal a new class of hydrothermal system. Nat. Commun. 6:10150. doi: 10.1038/ncomms10150

Hoffman, C. L., Nicholas, S. L., Ohnemus, D. C., Fitzsimmons, J. N., Sherrell, R. M., German, C. R., et al. (2018). Near-field iron and carbon chemistry of nonbuoyant hydrothermal plume particles, Southern East Pacific Rise $15^{\circ} \mathrm{S}$. Mar. Chem. 201, 183-197. doi: 10.1016/j.marchem.2018.01.011

Hourdez, S., and Lallier, F. H. (2007). Adaptations to hypoxia in hydrothermalvent and cold-seep invertebrates. Rev. Environ. Sci. Biotechnol. 6, 143-159. doi: 10.1007/s11157-006-9110-3

Huber, J. A., and Holden, J. F. (2008). "Modeling the impact of diffuse vent microorganisms along mid-ocean ridges and flanks," in Geophysical Monograph Series, eds R. P. Lowell, J. S. Seewald, A. Metaxas, and M. R. Perfit (Washington, DC: American Geophysical Union), 215-231.

Huber, J. A., Mark Welch, D. B., Morrison, H. G., Huse, S. M., Neal, P. R., Butterfield, D. A., et al. (2007). Microbial population structures in the deep marine biosphere. Science 318, 97-100. doi: 10.1126/science.1146689

Hügler, M., Gärtner, A., and Imhoff, J. F. (2010). Functional genes as markers for sulfur cycling and $\mathrm{CO}_{2}$ fixation in microbial communities of hydrothermal vents of the Logatchev field: functional gene diversity in diffuse hydrothermal fluids. FEMS Microbiol. Ecol. 73, 526-537. doi: 10.1111/j.1574-6941.2010. 00919.x

Hügler, M., Huber, H., Molyneaux, S. J., Vetriani, C., and Sievert, S. M. (2007). Autotrophic $\mathrm{CO}_{2}$ fixation via the reductive tricarboxylic acid cycle in different lineages within the phylum Aquificae: evidence for two ways of citrate cleavage. Environ. Microbiol. 9, 81-92. doi: 10.1111/j.1462-2920.2006.01118.x

Hügler, M., and Sievert, S. M. (2011). Beyond the calvin cycle: autotrophic carbon fixation in the ocean. Annu. Rev. Mar. Sci. 3, 261-289. doi: 10.1146/annurevmarine-120709-142712

Hügler, M., Wirsen, C. O., Fuchs, G., Taylor, C. D., and Sievert, S. M. (2005). Evidence for autotrophic $\mathrm{CO}_{2}$ fixation via the reductive tricarboxylic acid cycle by members of the subdivision of Proteobacteria. J. Bacteriol. 187, 3020-3027. doi: 10.1128/JB.187.9.3020-3027.2005

Husson, B., Sarradin, P.-M., Zeppilli, D., and Sarrazin, J. (2017). Picturing thermal niches and biomass of hydrothermal vent species. Deep Sea Res. Part II Top. Stud. Oceanogr. 137, 6-25. doi: 10.1016/j.dsr2.2016.05.028

Ishibashi, J.-I., Noguchi, T., Toki, T., Miyabe, S., Yamagami, S., Onishi, Y., et al. (2014). Diversity of fluid geochemistry affected by processes during fluid upwelling in active hydrothermal fields in the Izena Hole, the middle Okinawa Trough back-arc basin. Geochem. J. 48, 357-369. doi: 10.2343/geochemj.2.0311

Johnson, K. S., Childress, J. J., Beehler, C. L., and Sakamoto, C. M. (1994). Biogeochemistry of hydrothermal vent mussel communities: the deep-sea 
analogue to the intertidal zone. Deep Sea Res. Part I Oceanogr. Res. Pap. 41, 993-1011. doi: 10.1016/0967-0637(94)90015-9

Johnson, K. S., Childress, J. J., Hessler, R. R., Sakamoto-Arnold, C. M., and Beehler, C. L. (1988a). Chemical and biological interactions in the rose garden hydrothermal vent field. Galapagos spreading center. Deep Sea Res. Part A Oceanogr. Res. Pap. 35, 1723-1744. doi: 10.1016/0198-0149(88)90046-5

Johnson, K. S., Childress, J. J., and Beehler, C. L. (1988b). Short-term temperature variability in the Rose Garden hydrothermal vent field: an unstable deep-sea environment. Deep Sea Res. Part A Oceanogr. Res. Pap. 35, 1711-1721. doi: 10.1016/0198-0149(88)90045-3

Juniper, S. K., Sarrazin, J., and Grehan, A. (1998). Remote sensing of organism density and biomass at hydrothermal vents. Cah. Biol. Mar. 39, 245-247.

Kashefi, K. (2003). Extending the upper temperature limit for life. Science 301, 934-934. doi: 10.1126/science. 1086823

Kato, S., Shibuya, T., Takaki, Y., Hirai, M., Nunoura, T., and Suzuki, K. (2018). Genome-enabled metabolic reconstruction of dominant chemosynthetic colonizers in deep-sea massive sulfide deposits: chemosynthetic ecosystem fuelled by metal sulfides. Environ. Microbiol. 20, 862-877. doi: 10.1111/14622920.14032

Kato, S., Takano, Y., Kakegawa, T., Oba, H., Inoue, K., Kobayashi, C., et al. (2010). Biogeography and biodiversity in sulfide structures of active and inactive vents at deep-sea hydrothermal fields of the southern mariana trough. Appl. Environ. Microbiol. 76, 2968-2979. doi: 10.1128/AEM.00478-10

Kelley, D. S., Larson, J. A., Früh-Green, J. L., Yoerger, D. F., Shank, T. M., Butterfield, D. A., et al. (2005). A serpentinite-hosted ecosystem: the lost city hydrothermal field. Science 307, 1428-1434. doi: 10.1126/science.1102556

Kelley, D. S., Karson, J. A., Blackman, D. K., Früh-Green, G. L., Butterfield, D. A., Lilley, M. D., et al. (2001). An off-axis hydrothermal vent field near the Mid-Atlantic Ridge at $30^{\circ}$ N. Nature 412, 145-149. doi: 10.1038/35084000

Kelley, D. S., and Shank, T. M. (2010). "Hydrothermal systems: a decade of discovery in slow spreading environments," in Geophysical Monograph Series, eds P. A. Rona, C. W. Devey, J. Dyment, and B. J. Murton (Washington, DC: American Geophysical Union), 369-407.

Koschinsky, A., Seifert, R., Halbach, P., Bau, M., Brasse, S., de Carvalho, L. M., et al. (2002). Geochemistry of diffuse low-temperature hydrothermal fluids in the North Fiji basin. Geochim. Cosmochim. Acta 66, 1409-1427. doi: 10.1016/ S0016-7037(01)00855-9

Kumagai, H., Nakamura, K., Toki, T., Morishita, T., Okino, K., Ishibashi, J.-I., et al. (2008). Geological background of the Kairei and Edmond hydrothermal fields along the Central Indian Ridge: implications of their vent fluids' distinct chemistry. Geofluids 8, 239-251. doi: 10.1111/j.1468-8123.2008.00223.x

Lalou, C., Brichet, E., and Lange, J. (1989). Fossil hydrothermal sulfide deposits at the Galapagos Spreading Centre near $85^{\circ} 00$ West: geological setting, mineralogy and chronology. Oceanol. Acta 12, 1-8.

Lalou, C., Reyss, J. L., and Brichet, E. (1998). "Age of sub-bottom sulfide samples at the TAG active mound," in Proceedings of the Ocean Drilling Program, 158 Scientific Results, eds P. M. Herzig, S. E. Humphris, D. J. Miller, and R. A. Zierenberg (College Station, TX: Ocean Drilling Program). doi: 10.2973/odp. proc.sr.158.214.1998

Lalou, C., Reyss, J.-L., Brichet, E., Arnold, M., Thompson, G., Fouquet, Y., et al. (1993). New age data for Mid-Atlantic Ridge hydrothermal sites: TAG and Snakepit chronology revisited. J. Geophys. Res. 98, 9705-9714. doi: 10.1029/ 92JB01898

Lartaud, F., Little, C. T. S., de Rafelis, M., Bayon, G., Dyment, J., Ildefonse, B., et al. (2011). Fossil evidence for serpentinization fluids fueling chemosynthetic assemblages. Proc. Natl. Acad. Sci. U.S.A. 108, 7698-7703. doi: 10.1073/pnas. 1009383108

Le Bris, N., and Duperron, S. (2010). "Chemosynthetic communities and biogeochemical energy pathways along the Mid-Atlantic Ridge: the case of Bathymodiolus azoricus," in Geophysical Monograph Series, eds P. A. Rona, C. W. Devey, J. Dyment, and B. J. Murton (Washington, DC: American Geophysical Union), 409-429.

Le Bris, N., and Gaill, F. (2007). How does the annelid Alvinella pompejana deal with an extreme hydrothermal environment? Rev. Environ. Sci. Biotechnol. 6, 197-221. doi: 10.1007/s11157-006-9112-1

Le Bris, N., and Gaill, F. (2010). "Microbial habitats associated with deep-sea hydrothermal vent invertebrates: insights from microanalysis and geochemical modeling," in The Vent and Seep Biota, ed. S. Kiel (Berlin: Springer), 51-71.
Le Bris, N., Govenar, B., Le Gall, C., and Fisher, C. R. (2006a). Variability of physicochemical conditions in $9^{\circ} 50^{\prime} \mathrm{N}$ EPR diffuse flow vent habitats. Mar. Chem. 98 , 167-182. doi: 10.1016/j.marchem.2005.08.008

Le Bris, N., Rodier, P., Sarradin, P.-M., and Le Gall, C. (2006b). Is temperature a good proxy for sulfide in hydrothermal vent habitats? Cah. Biol. Mar. 47, $465-470$.

Le Bris, N., Sarradin, P.-M., Birot, D., and Alayse-Danet, A.-M. (2000). A new chemical analyzer for in situ measurement of nitrate and total sulfide over hydrothermal vent biological communities. Mar. Chem. 72, 1-15. doi: 10.1016/ S0304-4203(00)00057-8

Le Bris, N., Sarradin, P.-M., and Caprais, J.-C. (2003). Contrasted sulphide chemistries in the environment of $13 \mathrm{~N}$ EPR vent fauna. Deep Sea Res. Part I Oceanogr. Res. Pap. 50, 737-747. doi: 10.1016/S0967-0637(03)00051-7

Le Bris, N., Sarradin, P.-M., and Pennec, S. (2001). A new deep-sea probe for in situ $\mathrm{pH}$ measurement in the environment of hydrothermal vent biological communities. Deep Sea Res. Part I Oceanogr. Res. Pap. 48, 1941-1951. doi: 10.1016/S0967-0637(00)00112-6

Le Bris, N., Zbinden, M., and Gaill, F. (2005). Processes controlling the physicochemical micro-environments associated with Pompeii worms. Deep Sea Res. Part I Oceanogr. Res. Pap. 52, 1071-1083. doi: 10.1016/j.dsr.2005.01.003

Levin, L. A., Baco, A. R., Bowden, D. A., Colaco, A., Cordes, E. E., Cunha, M. R., et al. (2016). Hydrothermal vents and methane seeps: rethinking the sphere of influence. Front. Mar. Sci. 3:72. doi: 10.3389/fmars.2016.00072

Levin, L. A., Mendoza, G. F., Konotchick, T., and Lee, R. (2009). Macrobenthos community structure and trophic relationships within active and inactive Pacific hydrothermal sediments. Deep Sea Res. Part II Top. Stud. Oceanogr. 56, 1632-1648. doi: 10.1016/j.dsr2.2009.05.010

Li, J., Cui, J., Yang, Q., Cui, G., Wei, B., Wu, Z., et al. (2017). Oxidative weathering and microbial diversity of an inactive seafloor hydrothermal sulfide chimney. Front. Microbiol. 8:1378. doi: 10.3389/fmicb.2017.01378

Lilley, M. D., Butterfield, D. A., Lupton, J. E., and Olson, E. J. (2003). Magmatic events can produce rapid changes in hydrothermal vent chemistry. Nature 422 , 878-881. doi: 10.1038/nature01569

Loka Bharathi, P. A., and Shanta Nair, A. K. (2005). Rise of the dormant: simulated disturbance improves culturable abundance, diversity, and functions of deepsea bacteria of central indian ocean basin. Mar. Geosources Geotechnol. 23, 419-428. doi: 10.1080/10641190500446805

Lowell, R. P., Houghton, J. L., Farough, A., Craft, K. L., Larson, B. I., and Meile, C. D. (2015). Mathematical modeling of diffuse flow in seafloor hydrothermal systems: the potential extent of the subsurface biosphere at midocean ridges. Earth Planet. Sci. Lett. 425, 145-153. doi: 10.1016/j.epsl.2015. 05.047

Luther, G., Gartman, A., Yücel, M., Madison, A., Moore, T., Nees, H., et al. (2012). Chemistry, temperature, and faunal distributions at diffuse-flow hydrothermal vents: comparison of two geologically distinct ridge systems. Oceanography 25 , 234-245. doi: 10.5670/oceanog.2012.22

Luther, G. W., Glazer, B. T., Ma, S., Trouwborst, R. E., Moore, T. S., Metzger, E., et al. (2008). Use of voltammetric solid-state (micro)electrodes for studying biogeochemical processes: laboratory measurements to real time measurements with an in situ electrochemical analyzer (ISEA). Mar. Chem. 108, 221-235. doi: $10.1016 /$ j.marchem.2007.03.002

Luther, G. W., Rozan, T. F., Taillefert, M., Nuzzio, D. B., Di Meo, C., Shank, T. M., et al. (2001). Chemical speciation drives hydrothermal vent ecology. Nature 410, 813-816. doi: 10.1038/35071069

Lutz, R. A., Shank, T. M., Fornari, D. J., Haymon, R. M., Lilley, M. D., Von Damm, K. L., et al. (1994). Rapid growth at deep-sea vents. Nature 371, 663-664. doi: $10.1038 / 371663 \mathrm{a} 0$

Lutz, R. A., Shank, T. M., Luther, G. W., Vetriani, C., Tolstoy, M., Nuzzio, D. B. et al. (2008). Interrelationships between vent fluid chemistry, temperature, seismic activity, and biological community structure at a mussel-dominated, deep-sea hydrothermal vent along the east pacific rise. J. Shellfish Res. 27, 177-190. doi: 10.2983/0730-8000(2008)27[177:IBVFCT]2.0.CO;2

Marcus, J., Tunnicliffe, V., and Butterfield, D. A. (2009). Post-eruption succession of macrofaunal communities at diffuse flow hydrothermal vents on Axial Volcano, Juan de Fuca Ridge, Northeast Pacific. Deep Sea Res. Part II Top. Stud. Oceanogr. 56, 1586-1598. doi: 10.1016/j.dsr2.2009.05.004

Markert, S., Arndt, C., Felbeck, H., Becher, D., Sievert, S. M., Hugler, M., et al. (2007). Physiological proteomics of the uncultured endosymbiont 
of Riftia pachyptila. Science 315, 247-250. doi: 10.1126/science.113 2913

Markert, S., Gardebrecht, A., Felbeck, H., Sievert, S. M., Klose, J., Becher, D., et al. (2011). Status quo in physiological proteomics of the uncultured Riftia pachyptila endosymbiont. Proteomics 11, 3106-3117. doi: 10.1002/pmic. 201100059

Marsh, L., Copley, J. T., Huvenne, V. A. I., Linse, K., Reid, W. D. K., Rogers, A. D., et al. (2012). Microdistribution of faunal assemblages at deep-sea hydrothermal vents in the southern ocean. PLoS One 7:e48348. doi: 10.1371/journal.pone. 0048348

Martins, I., Colaço, A., Dando, P. R., Martins, I., Desbruyères, D., Sarradin, P.M., et al. (2008). Size-dependent variations on the nutritional pathway of Bathymodiolus azoricus demonstrated by a C-flux model. Ecol. Model. 217, 59-71. doi: 10.1016/j.ecolmodel.2008.05.008

Martins, I., Colaço, A., Santos, R. S., Lesongeur, F., Godfroy, A., Sarradin, P.-M., et al. (2009). Relationship between the occurrence of filamentous bacteria on Bathymodiolus azoricus shell and the physiological and toxicological status of the vent mussel. J. Exp. Mar. Biol. Ecol. 376, 1-6. doi: 10.1016/j.jembe.2009. 05.001

McCollom, T. M. (2007). Geochemical constraints on sources of metabolic energy for chemolithoautotrophy in ultramafic-hosted deep-sea hydrothermal systems. Astrobiology 7, 933-950. doi: 10.1089/ast.2006. 0119

McCollom, T. M., and Amend, J. P. (2005). A thermodynamic assessment of energy requirements for biomass synthesis by chemolithoautotrophic microorganisms in oxic and anoxic environments. Geobiology 3, 135-144. doi: 10. 1111/j.1472-4669.2005.00045.x

McCollom, T. M., and Shock, E. L. (1997). Geochemical constraints on chemolithoautotrophic metabolism by microorganisms in seafloor hydrothermal systems. Geochim. Cosmochim. Acta 61, 4375-4391. doi: 10.1016/S0016-7037(97)00241-X

McNichol, J., Stryhanyuk, H., Sylva, S. P., Thomas, F., Musat, N., Seewald, J. S., et al. (2018). Primary productivity below the seafloor at deep-sea hot springs. Proc. Natl. Acad. Sci. U.S.A. 115, 6756-6761. doi: 10.1073/pnas.180435 1115

McNichol, J., Sylva, S. P., Thomas, F., Taylor, C. D., Sievert, S. M., and Seewald, J. S. (2016). Assessing microbial processes in deep-sea hydrothermal systems by incubation at in situ temperature and pressure. Deep Sea Res. Part I Oceanogr. Res. Pap. 115, 221-232. doi: 10.1016/j.dsr.2016.06.011

Meier, D. V., Pjevac, P., Bach, W., Hourdez, S., Girguis, P. R., Vidoudez, C., et al. (2017). Niche partitioning of diverse sulfur-oxidizing bacteria at hydrothermal vents. ISME J. 11, 1545-1558. doi: 10.1038/ismej.2017.37

Mengerink, K. J., Van Dover, C. L., Ardron, J., Baker, M., Escobar-Briones, E., Gjerde, K., et al. (2014). A call for deep-ocean stewardship. Science 344, 696-698. doi: 10.1126/science. 1251458

Millero, F. J., Sotolongo, S., and Izaguirre, M. (1987). The oxidation kinetics of $\mathrm{Fe}(\mathrm{II})$ in seawater. Geochim. Cosmochim. Acta 51, 793-801. doi: 10.1016/00167037(87)90093-7

Mittelstaedt, E., Escartín, J., Gracias, N., Olive, J.-A., Barreyre, T., Davaille, A., et al. (2012). Quantifying diffuse and discrete venting at the Tour Eiffel vent site, Lucky Strike hydrothermal field: heat flux tour Eiffel. Geochem. Geophys. Geosyst. 13, 1-18. doi: 10.1029/2011GC003991

Moalic, Y., Desbruyères, D., Duarte, C. M., Rozenfeld, A. F., Bachraty, C., and Arnaud-Haond, S. (2012). Biogeography revisited with network theory: retracing the history of hydrothermal vent communities. Syst. Biol. 61, 127-137. doi: $10.1093 /$ sysbio/syr088

Moore, T. S., Shank, T. M., Nuzzio, D. B., and Luther, G. W. (2009). Time-series chemical and temperature habitat characterization of diffuse flow hydrothermal sites at $9^{\circ} 50^{\prime} \mathrm{N}$ East Pacific Rise. Deep Sea Res. Part II Top. Stud. Oceanogr. 56, 1616-1621. doi: 10.1016/j.dsr2.2009.05.008

Mori, J. F., Scott, J. J., Hager, K. W., Moyer, C. L., Küsel, K., and Emerson, D. (2017). Physiological and ecological implications of an iron- or hydrogen-oxidizing member of the Zeta proteobacteria, Ghiorsea bivora, gen. nov., sp. nov. ISME J. 11, 2624-2636. doi: 10.1038/ismej.2017.132

Mottl, M. J., Seewald, J. S., Wheat, C. G., Tivey, M. K., Michael, P. J., Proskurowski, G., et al. (2011). Chemistry of hot springs along the eastern lau spreading center. Geochim. Cosmochim. Acta 75, 1013-1038. doi: 10.1016/j.gca. 2010.12.008
Mullineaux, L. S., Adams, D. K., Mills, S. W., and Beaulieu, S. E. (2010). Larvae from afar colonize deep-sea hydrothermal vents after a catastrophic eruption. Proc. Natl. Acad. Sci. U.S.A. 107, 7829-7834. doi: 10.1073/pnas.0913187107

Mullineaux, L. S., Fisher, C. R., Peterson, C. H., and Schaeffer, S. W. (2000). Tubeworm succession at hydrothermal vents: use of biogenic cues to reduce habitat selection error? Oecologia 123, 275-284. doi: 10.1007/s004420051014

Mullineaux, L. S., Le Bris, N., Mills, S. W., Henri, P., Bayer, S. R., Secrist, R. G., et al. (2012). Detecting the influence of initial pioneers on succession at deep-sea vents. PLoS One 7:e50015. doi: 10.1371/journal.pone.0050015

Mullineaux, L. S., Metaxas, A., Beaulieu, S. E., Bright, M., Gollner, S., Grupe, B. M., et al. (2018). Exploring the ecology of deep-sea hydrothermal vents in a metacommunity framework. Front. Mar. Sci. 5:49. doi: 10.3389/fmars.2018. 00049

Mullineaux, L. S., Peterson, C. H., Micheli, F., and Mills, S. W. (2003). Successional mechanism varies along a gradient in hydrothermal fluid flux at deep-sea vents. Ecol. Monogr. 73, 523-542. doi: 10.1890/02-0674

Nakagawa, S., and Takai, K. (2008). Deep-sea vent chemoautotrophs: diversity, biochemistry and ecological significance: chemoautotrophy in deep-sea vents. FEMS Microbiol. Ecol. 65, 1-14. doi: 10.1111/j.1574-6941.2008.00502.x

Nakagawa, S., Takaki, Y., Shimamura, S., Reysenbach, A.-L., Takai, K., and Horikoshi, K. (2007). Deep-sea vent -proteobacterial genomes provide insights into emergence of pathogens. Proc. Natl. Acad. Sci. U.S.A. 104, 12146-12150. doi: 10.1073 /pnas.0700687104

Nakamura, K., and Takai, K. (2014). Theoretical constraints of physical and chemical properties of hydrothermal fluids on variations in chemolithotrophic microbial communities in seafloor hydrothermal systems. Prog. Earth Planet. Sci. 1:5. doi: 10.1186/2197-4284-1-5

Nedoncelle, K., Lartaud, F., Contreira Pereira, L., Yücel, M., Thurnherr, A. M., Mullineaux, L., et al. (2015). Bathymodiolus growth dynamics in relation to environmental fluctuations in vent habitats. Deep Sea Res. Part I Oceanogr. Res. Pap. 106, 183-193. doi: 10.1016/j.dsr.2015.10.003

Nees, H. A., Moore, T. S., Mullaugh, K. M., Holyoke, R. R., Janzen, C. P., Ma, S., et al. (2008). Hydrothermal vent mussel habitat chemistry, pre- and posteruption at $9^{\circ} 50^{\prime}$ North on the East Pacific Rise. J. Shellfish Res. 27, 169-175. doi: 10.2983/0730-8000(2008)27[169:HVMHCP]2.0.CO;2

O’Brien, C. E., Giovannelli, D., Govenar, B., Luther, G. W., Lutz, R. A., Shank, T. M., et al. (2015). Microbial biofilms associated with fluid chemistry and megafaunal colonization at post-eruptive deep-sea hydrothermal vents. Deep Sea Res. Part II Top. Stud. Oceanogr. 121, 31-40. doi: 10.1016/j.dsr2.2015.07.020

Ohara, Y., Reagan, M. K., Fujikura, K., Watanabe, H., Michibayashi, K., Ishii, T., et al. (2012). A serpentinite-hosted ecosystem in the Southern Mariana Forearc. Proc. Natl. Acad. Sci. U.S.A. 109, 2831-2835. doi: 10.1073/pnas.1112005109

Olins, H. C., Rogers, D. R., Frank, K. L., Vidoudez, C., and Girguis, P. R. (2013). Assessing the influence of physical, geochemical and biological factors on anaerobic microbial primary productivity within hydrothermal vent chimneys. Geobiology 11, 279-293. doi: 10.1111/gbi.12034

Orcutt, B. N., Sylvan, J. B., Knab, N. J., and Edwards, K. J. (2011). Microbial ecology of the dark ocean above, at, and below the seafloor. Microbiol. Mol. Biol. Rev. 75, 361-422. doi: 10.1128/MMBR.00039-10

Pedersen, R. B., Rapp, H. T., Thorseth, I. H., Lilley, M. D., Barriga, F. J. A. S., Baumberger, T., et al. (2010). Discovery of a black smoker vent field and vent fauna at the Arctic Mid-Ocean Ridge. Nat. Commun. 1:126. doi: 10.1038/ ncomms1124

Perner, M., Hansen, M., Seifert, R., Strauss, H., Koschinsky, A., and Petersen, S. (2013). Linking geology, fluid chemistry, and microbial activity of basalt- and ultramafic-hosted deep-sea hydrothermal vent environments. Geobiology 11, 340-355. doi: 10.1111/gbi.12039

Perner, M., Seifert, R., Weber, S., Koschinsky, A., Schmidt, K., Strauss, H., et al. (2007). Microbial $\mathrm{CO}_{2}$ fixation and sulfur cycling associated with low-temperature emissions at the Lilliput hydrothermal field, southern MidAtlantic Ridge $\left(9^{\circ} \mathrm{S}\right)$ : microorganisms associated with low-temperature venting. Environ. Microbiol. 9, 1186-1201. doi: 10.1111/j.1462-2920.2007.01241.x

Pester, N. J., Ding, K., and Seyfried, W. E. (2014). Magmatic eruptions and iron volatility in deep-sea hydrothermal fluids. Geology 42, 255-258. doi: 10.1130/ G35079.1

Petersen, J. M., Zielinski, F. U., Pape, T., Seifert, R., Moraru, C., Amann, R., et al. (2011). Hydrogen is an energy source for hydrothermal vent symbioses. Nature 476, 176-180. doi: 10.1038/nature10325 
Podowski, E., Ma, S., Luther, G., Wardrop, D., and Fisher, C. (2010). Biotic and abiotic factors affecting distributions of megafauna in diffuse flow on andesite and basalt along the Eastern Lau Spreading Center, Tonga. Mar. Ecol. Prog. Ser. 418, 25-45. doi: 10.3354/meps08797

Ponsard, J., Cambon-Bonavita, M.-A., Zbinden, M., Lepoint, G., Joassin, A., Corbari, L., et al. (2013). Inorganic carbon fixation by chemosynthetic ectosymbionts and nutritional transfers to the hydrothermal vent host-shrimp Rimicaris exoculata. ISME J. 7, 96-109. doi: 10.1038/ismej.2012.87

Portail, M., Brandily, C., Cathalot, C., Colaço, A., Gélinas, Y., Husson, B., et al. (2018). Food-web complexity across hydrothermal vents on the Azores triple junction. Deep Sea Res. Part I Oceanogr. Res. Pap. 131, 101-120. doi: 10.1016/j. dsr.2017.11.010

Pradillon, F., Zbinden, M., Le Bris, N., Hourdez, S., Barnay, A.-S., and Gaill, F. (2009). Development of assemblages associated with alvinellid colonies on the walls of high-temperature vents at the East Pacific Rise. Deep Sea Res. Part II Top. Stud. Oceanogr. 56, 1622-1631. doi: 10.1016/j.dsr2.2009.05.009

Proskurowski, G., Lilley, M. D., Seewald, J. S., Fruh-Green, G. L., Olson, E. J., Lupton, J. E., et al. (2008). abiogenic hydrocarbon production at lost city hydrothermal field. Science 319, 604-607. doi: 10.1126/science.1151194

Pruis, M. J., and Johnson, H. P. (2004). Tapping into the sub-seafloor: examining diffuse flow and temperature from an active seamount on the Juan de Fuca Ridge. Earth Planet. Sci. Lett. 217, 379-388. doi: 10.1016/S0012-821X(03) 00607-1

Ragsdale, S. W., and Pierce, E. (2008). Acetogenesis and the Wood-Ljungdahl pathway of $\mathrm{CO}_{2}$ fixation. Biochim. Biophys. Acta Proteins Proteomics 1784, 1873-1898. doi: 10.1016/j.bbapap.2008.08.012

Ramirez-Llodra, E., Brandt, A., Danovaro, R., De Mol, B., Escobar, E., German, C. R., et al. (2010). Deep, diverse and definitely different: unique attributes of the world's largest ecosystem. Biogeosciences 7, 2851-2899. doi: 10.5194/bg-72851-2010

RamirezLlodra, E. R., Tyler, P. A., and Copley, J. T. P. (2000). Reproductive biology of three Caridean shrimp, Rimicaris exoculata, Chorocaris chacei and Mirocaris fortunata (Caridea: Decapoda), from hydrothermal vents. J. Mar. Biol. Assoc. U.K. 80, 473-484. doi: 10.1017/S0025315400002174

Ramondenc, P., Germanovich, L. N., Von Damm, K. L., and Lowell, R. P. (2006). The first measurements of hydrothermal heat output at $9^{\circ} 50^{\prime} \mathrm{N}$, East Pacific Rise. Earth Planet. Sci. Lett. 245, 487-497. doi: 10.1016/j.epsl.2006. 03.023

Ravaux, J., Hamel, G., Zbinden, M., Tasiemski, A. A., Boutet, I., Léger, N., et al. (2013). Thermal limit for metazoan life in question: in vivo heat tolerance of the pompeii worm. PLoS One 8:e64074. doi: 10.1371/journal.pone. 0064074

Reeves, E. P., Seewald, J. S., Saccocia, P., Bach, W., Craddock, P. R., Shanks, W. C., et al. (2011). Geochemistry of hydrothermal fluids from the PACMANUS, Northeast Pual and Vienna woods hydrothermal fields, Manus Basin, Papua New Guinea. Geochim. Cosmochim. Acta 75, 1088-1123. doi: 10.1016/ j.gca.2010.11.008

Resing, J. A., Lebon, G., Baker, E. T., Lupton, J. E., Embley, R. W., Massoth, G. J., et al. (2007). Venting of acid-sulfate fluids in a high-sulfidation setting at NW rota-1 submarine volcano on the Mariana Arc. Econ. Geol. 102, 1047-1061. doi: 10.2113/gsecongeo.102.6.1047

Resing, J. A., Sedwick, P. N., German, C. R., Jenkins, W. J., Moffett, J. W., Sohst, B. M., et al. (2015). Basin-scale transport of hydrothermal dissolved metals across the South Pacific Ocean. Nature 523, 200-203. doi: 10.1038/nature 14577

Reveillaud, J., Reddington, E., McDermott, J., Algar, C., Meyer, J. L., Sylva, S., et al. (2016). Subseafloor microbial communities in hydrogen-rich vent fluids from hydrothermal systems along the Mid-Cayman Rise: subseafloor microbes at Mid-Cayman Rise. Environ. Microbiol. 18, 1970-1987. doi: 10.1111/1462-2920. 13173

Reysenbach, A.-L., Hamamura, N., Podar, M., Griffiths, E., Ferreira, S., Hochstein, R., et al. (2009). Complete and draft genome sequences of six members of the aquificales. J. Bacteriol. 191, 1992-1993. doi: 10.1128/JB.01 645-08

Riou, V., Halary, S., Duperron, S., Bouillon, S., Elskens, M., Bettencourt, R., et al. (2008). Influence of $\mathrm{CH} 4$ and $\mathrm{H} 2 \mathrm{~S}$ availability on symbiont distribution, carbon assimilation and transfer in the dual symbiotic vent mussel Bathymodiolus azoricus. Biogeosciences 5, 1681-1691. doi: 10.5194/bg-5-1681-2008
Robidart, J., Callister, S. J., Song, P., Nicora, C. D., Wheat, C. G., and Girguis, P. R. (2013). Characterizing microbial community and geochemical dynamics at hydrothermal vents using osmotically driven continuous fluid samplers. Environ. Sci. Technol. 47, 4399-4407. doi: 10.1021/es303 7302

Robidart, J. C., Bench, S. R., Feldman, R. A., Novoradovsky, A., Podell, S. B., Gaasterland, T., et al. (2008). Metabolic versatility of the Riftia pachyptila endosymbiont revealed through metagenomics. Environ. Microbiol. 10, $727-$ 737. doi: 10.1111/j.1462-2920.2007.01496.x

Robidart, J. C., Roque, A., Song, P., and Girguis, P. R. (2011). Linking hydrothermal geochemistry to organismal physiology: physiological versatility in Riftia pachyptila from sedimented and basalt-hosted vents. PLoS One 6:e21692. doi: 10.1371/journal.pone.0021692

Rogers, A. D., Tyler, P. A., Connelly, D. P., Copley, J. T., James, R., Larter, R. D., et al. (2012). The discovery of New Deep-Sea hydrothermal vent communities in the southern ocean and implications for biogeography. PLoS Biol. 10:e1001234. doi: 10.1371/journal.pbio.1001234

Rona, P. A., Petersen, S., Becker, K., Von Herzen, R. P., Hannington, M. D., Herzig, P. M., et al. (1996). Heat flow and mineralogy of TAG relict high-temperature hydrothermal zones: mid-atlantic ridge $26^{\circ} \mathrm{N}, 45^{\circ} \mathrm{W}$. Geophys. Res. Lett. 23, 3507-3510. doi: 10.1029/96GL03257

Rubin, K., Soule, S. A., Chadwick, W., Fornari, D., Clague, D., Embley, R., et al. (2012). Volcanic Eruptions in the Deep Sea. Oceanography 25, 142-157. doi: 10.5670/oceanog.2012.12

Sander, S. G., and Koschinsky, A. (2011). Metal flux from hydrothermal vents increased by organic complexation. Nat. Geosci. 4, 145-150. doi: 10.1038/ ngeo 1088

Sanders, J. G., Beinart, R. A., Stewart, F. J., Delong, E. F., and Girguis, P. R. (2013). Metatranscriptomics reveal differences in in situ energy and nitrogen metabolism among hydrothermal vent snail symbionts. ISME J. 7, 1556-1567. doi: 10.1038/ismej.2013.45

Sands, C. M., Connelly, D. P., Statham, P. J., and German, C. R. (2012). Size fractionation of trace metals in the Edmond hydrothermal plume. Central Indian Ocean. Earth Planet. Sci. Lett. 31, 15-22. doi: 10.1016/j.epsl.2011. 12.031

Santos, R. S., Morato, T., and Barriga, F. J. A. S. (2012). "Increasing pressure at the bottom of the ocean," in Natural Resources, Sustainability and Humanity, eds A. Mendonca, A. Cunha, and R. Chakrabarti (Dordrecht: Springer), 69-81. doi: 10.1007/978-94-007-1321-5_5

Sarradin, P. M., Caprais, J. C., Briand, P., Gaill, F., Shillito, B., and DesbruyeÌres, D. (1998). Chemical and thermal description of the environment of the Genesis hydrothermal vent community $\left(13^{\circ} \mathrm{N}, \mathrm{EPR}\right)$. Cahiers de Biologie Marine 39, $159-167$.

Sarrazin, J., Cuvelier, D., Peton, L., Legendre, P., and Sarradin, P. M. (2014). High-resolution dynamics of a deep-sea hydrothermal mussel assemblage monitored by the EMSO-Açores MoMAR observatory. Deep Sea Res. Part I Oceanogr. Res. Papers 90, 62-75. doi: 10.1016/j.dsr.2014. 04.004

Sarrazin, J., and Juniper, S. (1999). Biological characteristics of a hydrothermal edifice mosaic community. Mar. Ecol. Prog. Series 185, 1-19. doi: 10.3354/ meps 185001

Sarrazin, J., Legendre, P., de Busserolles, F., Fabri, M.-C., Guilini, K., Ivanenko, V. N., et al. (2015). Biodiversity patterns, environmental drivers and indicator species on a high-temperature hydrothermal edifice, Mid-Atlantic Ridge. Deep Sea Res. Part II Top. Stud. Oceanogr. 121, 177-192. doi: 10.1016/j.dsr2.2015.04. 013

Sarrazin, J., Robigou, V., Juniper, S., and Delaney, J. (1997). Biological and geological dynamics over four years on a high-temperature sulfide structure at the Juan de Fuca Ridge hydrothermal observatory. Mar. Ecol. Prog. Ser. 153, 5-24. doi: 10.3354/meps153005

Scheirer, D. S., Shank, T. M., and Fornari, D. J. (2006). Temperature variations at diffuse and focused flow hydrothermal vent sites along the northern East Pacific Rise. Geochem. Geophys. Geosyst. 7, 1-23. doi: 10.1029/2005GC0 01094

Schmidt, C., Vuillemin, R., Le Gall, C., Gaill, F., and Le Bris, N. (2008). Geochemical energy sources for microbial primary production in the environment of hydrothermal vent shrimps. Mar. Chem. 108, 18-31. doi: 10. 1016/j.marchem.2007.09.009 
Schmidt, K., Koschinsky, A., Garbe-Schönberg, D., de Carvalho, L. M., and Seifert, R. (2007). Geochemistry of hydrothermal fluids from the ultramafichosted Logatchev hydrothermal field, $15^{\circ} \mathrm{N}$ on the Mid-Atlantic Ridge: temporal and spatial investigation. Chem. Geol. 242, 1-21. doi: 10.1016/j. chemgeo.2007.01.023

Seewald, J. S., Reeves, E. P., Bach, W., Saccocia, P. J., Craddock, P. R., Shanks, W. C., et al. (2015). Submarine venting of magmatic volatiles in the Eastern Manus Basin, Papua New Guinea. Geochim. Cosmochim. Acta 163, 178-199. doi: 10.1016/j.gca.2015.04.023

Sen, A., Becker, E. L., Podowski, E. L., Wickes, L. N., Ma, S., Mullaugh, K. M., et al. (2013). Distribution of mega fauna on sulfide edifices on the Eastern Lau spreading center and Valu Fa Ridge. Deep Sea Res. Part I Oceanogr. Res. Pap. 72, 48-60. doi: 10.1016/j.dsr.2012.11.003

Sen, A., Podowski, E. L., Becker, E. L., Shearer, E. A., Gartman, A., Yücel, M., et al. (2014). Community succession in hydrothermal vent habitats of the Eastern Lau Spreading Center and Valu Fa Ridge, Tonga. Limnol. Oceanogr. 59, 1510-1528. doi: 10.4319/lo.2014.59.5.1510

Shank, T. M., Fornari, D. J., Von Damm, K. L., Lilley, M. D., Haymon, R. M., and Lutz, R. A. (1998). Temporal and spatial patterns of biological community development at nascent deep-sea hydrothermal vents $\left(9^{\circ} 50^{\prime} \mathrm{N}\right.$, East Pacific Rise). Deep Sea Res. Part II Top. Stud. Oceanogr. 45, 465-515. doi: 10.1016/ S0967-0645(97)00089-1

Shiba, H., Kawasumi, T., Igarashi, Y., Kodama, T., and Minoda, Y. (1985). The $\mathrm{CO}_{2}$ assimilation via the reductive tricarboxylic acid cycle in an obligately autotrophic, aerobic hydrogen-oxidizing bacterium. Hydrogenobacter thermophilus. Arch. Microbiol. 141, 198-203. doi: 10.1007/BF00 408058

Sievert, S., and Vetriani, C. (2012). Chemoautotrophy at deep-sea vents: past. Present, and Future. Oceanography 25, 218-233. doi: 10.5670/oceanog.2012.21

Sievert, S. M., Hügler, M., Taylor, C. D., and Wirsen, C. O. (2008). "Sulfur oxidation at deep-sea hydrothermal vents," in Microbial Sulfur Metabolism, eds C. Dahl and C. G. Friedrich (Berlin: Springer), 238-258.

Sohn, R. A. (2007). Stochastic analysis of exit fluid temperature records from the active TAG hydrothermal mound (Mid-Atlantic Ridge, $26^{\circ} \mathrm{N}$ ): 1 . Modes of variability and implications for subsurface flow. J. Geophys. Res. 112, 1-16. doi: 10.1029/2006JB004435

Spiess, F. N., Macdonald, K. C., Atwater, T., Ballard, R., Carranza, A., Cordoba, D., et al. (1980). East pacific rise: hot springs and geophysical experiments. Science 207, 1421-1433. doi: 10.1126/science.207.4438.1421

Sylvan, J. B., Pyenson, B. C., Rouxel, O., German, C. R., and Edwards, K. J. (2012). Time-series analysis of two hydrothermal plumes at $9^{\circ} 50^{\prime} \mathrm{N}$ East Pacific Rise reveals distinct, heterogeneous bacterial populations: microbiology of hydrothermal plumes at 9N EPR. Geobiology 10, 178-192. doi: 10.1111/j.14724669.2011.00315.x

Tagliabue, A., Bopp, L., Dutay, J.-C., Bowie, A. R., Chever, F., Jean-Baptiste, P., et al. (2010). Hydrothermal contribution to the oceanic dissolved iron inventory. Nat. Geosci. 3, 252-256. doi: 10.1038/ngeo818

Takai, K., Gamo, T., Tsunogai, U., Nakayama, N., Hirayama, H., Nealson, K., et al. (2004). Geochemical and microbiological evidence for a hydrogenbased, hyperthermophilic subsurface lithoautotrophic microbial ecosystem (HyperSLiME) beneath an active deep-sea hydrothermal field. Extremophiles 8 , 269-282. doi: 10.1007/s00792-004-0386-3

Takai, K., Nakagawa, S., Reysenbach, A.-L., and Hoek, J. (2006). "Microbial ecology of mid-ocean ridges and back-arc basins," in Geophysical Monograph Series, eds D. M. Christie, C. R. Fisher, S.-M. Lee, and S. Givens (Washington, DC: American Geophysical Union), 185-213.

Takai, K., and Nakamura, K. (2011). Archaeal diversity and community development in deep-sea hydrothermal vents. Curr. Opin. Microbiol. 14, 282291. doi: 10.1016/j.mib.2011.04.013

Taylor, C. D., Wirsen, C. O., and Gaill, F. (1999). Rapid microbial production of filamentous sulfur mats at hydrothermal vents. Appl. Environ. Microbiol. 65, 2253-2255.

Thomas, T. R. A., Das, A., and Ponnapakkam Adikesavan, L. (2018). A review on the phylogeography of potentially chemoautotrophic bacteria from major vent and seep fauna and their contribution to primary production. Geomicrobiol. J. 35, 612-634. doi: 10.1080/01490451.2018.1440035

Tivey, M. K. (2004). "Environmental conditions within active seafloor vent structures: sensitivity to vent fluid composition and fluid flow," in Geophysical
Monograph Series, eds W. S. D. Wilcock, E. F. DeLong, D. S. Kelley, J. A. Baross, and S. Craig Cary (Washington, DC: American Geophysical Union), 137-152.

Tivey, M. (2007). Generation of seafloor hydrothermal vent fluids and associated mineral deposits. Oceanography 20, 50-65. doi: 10.5670/oceanog.2007.80

Tsurumi, M., and Tunnicliffe, V. (2001). Characteristics of a hydrothermal vent assemblage on a volcanically active segment of Juan de Fuca Ridge, northeast Pacific. Can. J. Fish. Aquat. Sci. 58, 530-542. doi: 10.1139/cjfas-58-3-530

Tunnicliffe, V., Baross, J. A., Gebruck, A. V., Giere, O., Holland, M. E., Koschinsky, A., et al. (2003). "Group report: what are the interactions between biotic processes at vents and physical, chemical, and geological conditions," in Energy and Mass Transfer in Marine Hydrothermal Systems, eds P. E. Halbach, V. Tunnicliffe, and J. R. Hein (Berlin: Dahlem University Press).

Tunnicliffe, V., Davies, K. T. A., Butterfield, D. A., Embley, R. W., Rose, J. M., and Chadwick, W. W. Jr. (2009). Survival of mussels in extremely acidic waters on a submarine volcano. Nat. Geosci. 2, 344-348. doi: 10.1038/ngeo500

Tunnicliffe, V., Embley, R. W., Holden, J. F., Butterfield, D. A., Massoth, G. J., and Juniper, S. K. (1997). Biological colonization of new hydrothermal vents following an eruption on Juan de Fuca Ridge. Deep Sea Res. Part I Oceanogr. Res. Pap. 44, 1627-1644. doi: 10.1016/S0967-0637(97)000411

Urcuyo, I. A., Massoth, G. J., Julian, D., and Fisher, C. R. (2003). Habitat, growth and physiological ecology of a basaltic community of Ridgeia piscesae from the Juan de Fuca Ridge. Deep Sea Res. Part I Oceanogr. Res. Pap. 50, 763-780. doi: 10.1016/S0967-0637(03)00061-X

Van Dover, C. (2000). The Ecology of Deep-Sea Hydrothermal Vents. Princeton, NJ: Princeton University Press.

Van Dover, C. L. (2011). Mining seafloor massive sulphides and biodiversity: what is at risk? ICES J. Mar. Sci. 68, 341-348. doi: 10.1093/icesjms/fsq086

Van Dover, C. L., Fry, B., Grassle, J. F., Humphris, S., and Rona, P. A. (1988). Feeding biology of the shrimp Rimicaris exoculata at hydrothermal vents on the Mid-Atlantic Ridge. Mar. Biol. 98, 209-216. doi: 10.1007/BF003 91196

Von Damm, K. L. (1995). "Controls on the chemistry and temporal variability of seafloor hydrothermal fluids," in Geophysical Monograph Series, eds S. E. Humphris, R. A. Zierenberg, L. S. Mullineaux, and R. E. Thomson (Washington, DC: American Geophysical Union), 222-247.

Von Damm, K. L., Buttermore, L. G., Oosting, S. E., Bray, A. M., Fornari, D. J., Lilley, M. D., et al. (1997). Direct observation of the evolution of a seafloor "black smoker" from vapor to brine. Earth Planet. Sci. Lett. 149, 101-111. doi: 10.1016/S0012-821X(97)00059-9

Von Damm, K. L., and Lilley, M. D. (2004). "Diffuse flow hydrothermal fluids from $9^{\circ} 50^{\prime} \mathrm{N}$ East Pacific Rise: origin, evolution and biogeochemical controls," in Geophysical Monograph Series, eds W. S. D. Wilcock, E. F. DeLong, D. S. Kelley, J. A. Baross, and S. Craig Cary (Washington, DC: American Geophysical Union), 245-268.

Von Damm, K. L., Lilley, M. D., Shanks, W. C., Brockington, M., Bray, A. M., O'Grady, K. M., et al. (2003). Extraordinary phase separation and segregation in vent fluids from the southern East Pacific Rise. Earth Planet. Sci. Lett. 206, 365-378. doi: 10.1016/S0012-821X(02)01081-6

Waite, D. W., Vanwonterghem, I., Rinke, C., Parks, D. H., Zhang, Y., Takai, K., et al. (2017). Comparative genomic analysis of the class Epsilon proteobacteria and proposed reclassification to Epsilon bacteraeota (phyl. nov.). Front. Microbiol. 8:682. doi: 10.3389/fmicb.2017.00682

Waite, T. J., Moore, T. S., Childress, J. J., Hsu-Kim, H., Mullaugh, K. M., Nuzzio, D. B., et al. (2008). Variation in sulfur speciation with shellfish presence at a Lau Basin diffuse flow vent site. J. Shellfish Res. 27, 163-168. doi: 10.2983/07308000(2008)27[163:VISSWS]2.0.CO;2

Wang, F., Zhou, H., Meng, J., Peng, X., Jiang, L., Sun, P., et al. (2009). GeoChipbased analysis of metabolic diversity of microbial communities at the Juan de Fuca Ridge hydrothermal vent. Proc. Natl. Acad. Sci. U.S.A. 106, 4840-4845. doi: 10.1073/pnas.0810418106

Wang, H., Zhang, J., Sun, Q., Lian, C., and Sun, L. (2017). A comparative study revealed first insights into the diversity and metabolisms of the microbial communities in the sediments of Pacmanus and Desmos hydrothermal fields. PLoS One 12:e0181048. doi: 10.1371/journal.pone. 0181048

Wankel, S. D., Germanovich, L. N., Lilley, M. D., Genc, G., DiPerna, C. J., Bradley, A. S., et al. (2011). Influence of subsurface biosphere on geochemical fluxes from diffuse hydrothermal fluids. Nat. Geosci. 4, 461-468. doi: 10.1038/ngeo1183 
Watsuji, T., Yamamoto, A., Takaki, Y., Ueda, K., Kawagucci, S., and Takai, K. (2014). Diversity and methane oxidation of active epibiotic methanotrophs on live Shinkaia crosnieri. ISME J. 8, 1020-1031. doi: 10.1038/ismej.2013.226

Weiss, M. C., Sousa, F. L., Mrnjavac, N., Neukirchen, S., Roettger, M., NelsonSathi, S., et al. (2016). The physiology and habitat of the last universal common ancestor. Nat. Microbiol. 1, 1-8. doi: 10.1038/nmicrobiol.2016.116

Wendeberg, A., Zielinski, F. U., Borowski, C., and Dubilier, N. (2012). Expression patterns of mRNAs for methanotrophy and thiotrophy in symbionts of the hydrothermal vent mussel Bathymodiolus puteoserpentis. ISME J. 6, 104-112. doi: 10.1038/ismej.2011.81

Wu, J., Wells, M. L., and Rember, R. (2011). Dissolved iron anomaly in the deep tropical-subtropical Pacific: evidence for long-range transport of hydrothermal iron. Geochim. Cosmochim. Acta 75, 460-468. doi: 10.1016/j.gca.2010.10.024

Xie, W., Wang, F., Guo, L., Chen, Z., Sievert, S. M., Meng, J., et al. (2011). Comparative metagenomics of microbial communities inhabiting deep-sea hydrothermal vent chimneys with contrasting chemistries. ISME J. 5, 414-426. doi: 10.1038 /ismej.2010.144

Yamamoto, M., and Takai, K. (2011). Sulfur metabolisms in epsilon- and gammaProteobacteria in deep-sea hydrothermal fields. Front. Microbiol. 2:192. doi: 10.3389/fmicb.2011.00192

Yücel, M., Gartman, A., Chan, C. S., and Luther, G. W. (2011). Hydrothermal vents as a kinetically stable source of iron-sulphide-bearing nanoparticles to the ocean. Nat. Geosci. 4, 367-371. doi: 10.1038/ngeo1148

Yücel, M., and Luther, G. W. (2013). Temporal trends in vent fluid iron and sulfide chemistry following the 2005/2006 eruption at East Pacific Rise, $9^{\circ} 50^{\prime} \mathrm{N}$ : Fe-S chemistry after 2006 EPR eruption. Geochem. Geophys. Geosyst. 14, 759-765. doi: 10.1002 /ggge.20088
Zeppilli, D., Leduc, D., Fontanier, C., Fontaneto, D., Fuchs, S., Gooday, A. J., et al. (2018). Characteristics of meiofauna in extreme marine ecosystems: a review. Mar. Biodivers. 48, 35-71. doi: 10.1007/s12526-0170815-z

Zhang, J.-Z., and Millero, F. J. (1993). "Kinetics of oxidation of hydrogen sulfide in natural waters," in Environmental Geochemistry of Sulfide Oxidation, eds C. N. Alpers and D. W. Blowes (Washington, DC: American Chemical Society), 393-409. doi: 10.1021/bk-1994-0550.ch026

Zielinski, F. U., Gennerich, H.-H., Borowski, C., Wenzhöfer, F., and Dubilier, N. (2011). In situ measurements of hydrogen sulfide, oxygen, and temperature in diffuse fluids of an ultramafic-hosted hydrothermal vent field (Logatchev, $14^{\circ} 45^{\prime} \mathrm{N}$, Mid-Atlantic Ridge): implications for chemosymbiotic bathymodiolin mussels: in situ measurements at vent mussel beds. Geochem. Geophys. Geosyst. 12, 1-21. doi: 10.1029/2011GC0 03632

Conflict of Interest Statement: The authors declare that the research was conducted in the absence of any commercial or financial relationships that could be construed as a potential conflict of interest.

Copyright (c) 2019 Le Bris, Yücel, Das, Sievert, LokaBharathi and Girguis. This is an open-access article distributed under the terms of the Creative Commons Attribution License (CC BY). The use, distribution or reproduction in other forums is permitted, provided the original author(s) and the copyright owner(s) are credited and that the original publication in this journal is cited, in accordance with accepted academic practice. No use, distribution or reproduction is permitted which does not comply with these terms. 